NBER WORKING PAPER SERIES

\title{
THE TRADEOFF BETWEEN MORTGAGE PREPAYMENTS AND TAX-DEFERRED RETIREMENT SAVINGS
}

\author{
Gene Amromin \\ Jennifer Huang \\ Clemens Sialm \\ Working Paper 12502 \\ http://www.nber.org/papers/w12502
NATIONAL BUREAU OF ECONOMIC RESEARCH
1050 Massachusetts Avenue
Cambridge, MA 02138
August 2006

We thank Jeff Brown, Keith Brown, John Campbell, Courtney Coile, Gary Engelhardt, Amy Finkelstein, Leora Friedberg, Roger Gordon, Anil Kumar, Brigitte Madrian, Olivia Mitchell, Robert Parrino, Jim Poterba, Josh Rauh, Scott Weisbenner, Michelle White, and seminar participants at the Federal Reserve Bank of Chicago, the Trans-Atlantic Public Economics Seminar on Public Policy and Retirement in Uppsala (Sweden), the University of Michigan at Ann Arbor, and the University of Texas at Austin for helpful comments and discussions. We are very grateful to Kevin Moore of the Board of Governors for support with the SCF data. The views expressed herein are those of the author(s) and do not necessarily reflect the views of the National Bureau of Economic Research.

(O2006 by Gene Amromin, Jennifer Huang and Clemens Sialm. All rights reserved. Short sections of text, not to exceed two paragraphs, may be quoted without explicit permission provided that full credit, including () notice, is given to the source. 
The Tradeoff between Mortgage Prepayments and Tax-Deferred Retirement Savings

Gene Amromin, Jennifer Huang and Clemens Sialm

NBER Working Paper No. 12502

August 2006

JEL No. G11, G18, H24, H31

\begin{abstract}
We show that a significant number of households can perform a tax arbitrage by cutting back on their additional mortgage payments and increasing their contributions to tax-deferred accounts (TDA). Using data from the Survey of Consumer Finances, we show that about $38 \%$ of U.S. households that are accelerating their mortgage payments instead of saving in tax-deferred accounts are making the wrong choice. For these households, reallocating their savings can yield a mean benefit of 11 to 17 cents per dollar, depending on the choice of investment assets in the TDA. In the aggregate, these mis-allocated savings are costing U.S. households as much as 1.5 billion dollars per year. Finally, we show empirically that this inefficient behavior is unlikely to be driven by liquidity considerations and that self-reported debt aversion and risk aversion variables explain to some extent the preference for paying off debt obligations early and hence the propensity to forgo our proposed tax arbitrage.
\end{abstract}

Gene Amromin

Federal Reserve Bank of Chicago

230 South LaSalle Street

Chicago, IL 60604

gamromin@frbchi.org

Jennifer Huang

Department of Finance

B6000

McCombs School of Business

University of Texas at Austin

Austin, TX 78712

jennifer.huang@mccombs.utexas.edu

Clemens Sialm

University of Michigan Business School

701 Tappan Street

D3219

Ann Arbor, MI 48109-1234

and NBER

sialm@umich.edu 
"Neither a borrower nor a lender be;

For loan oft loses both itself and friend, And borrowing dulls the edge of husbandry."

- William Shakespeare

\section{Introduction}

Many households are reluctant to participate in financial markets either as lenders or as borrowers. According to the 2001 Survey of Consumer Finances, nearly half of U.S. households do not own stocks and more than one third of the households eligible for employer-sponsored retirement plans do not contribute at all to such plans. Furthermore, some households are also reluctant to carry debt. At a first glance, this runs counter to stylized facts on the proliferation of consumer borrowing, especially in unsecured credit markets. Yet, a surprising number of households accelerate paydowns of their mortgage loans, which account for a much bigger share of their debt. We show that these choices generate substantial monetary costs for a significant number of households.

This paper focuses on two of the most important financial decisions of households: retirement savings and home-ownership borrowing. Many households, at one time or another, face the trade-off between paying an extra dollar off the remaining mortgage on their house and saving that extra dollar in tax-qualified retirement accounts. In a world without frictions, paying off mortgage loans early and investing in retirement accounts would be equivalent saving decisions. In reality, however, taxes and transaction costs play a key role in the determination of the effective borrowing and lending rates. We show that, under certain conditions, it becomes a tax-arbitrage to reduce mortgage prepayments and to increase contributions to tax-deferred accounts (TDA). ${ }^{1}$

Mortgage interest payments are deductible from taxable income for households that

\footnotetext{
${ }^{1}$ Throughout the paper, we use the term "mortgage prepayment" to denote extra payments on an existing mortgage or taking out a mortgage with a maturity shorter than the standard 30 years. Short maturity mortgages carry higher periodic payments, which can be considered committed "prepayments" in the same sense as writing extra checks to the mortgage company. We do not include mortgage refinancing in our definition of "prepayments," although this interpretation is common in the industry.
} 
itemize their deductions, while investment income in retirement accounts remains effectively tax-exempt. ${ }^{2}$ Hence, households earn pre-tax returns $\left(r_{L}\right)$ in their retirement accounts and pay after-tax rates $(1-\tau) r_{B}$ on their mortgage borrowing. Although the borrowing rate $\left(r_{B}\right)$ on the mortgage is likely higher than the investment rate $\left(r_{L}\right)$ for an asset with similar risk properties, we show that, as long as $r_{L}>(1-\tau) r_{B}$, households are generally better off saving in a TDA instead of prepaying their mortgage. Given the simplicity of this strategy, it is reasonable to ask whether and to what extent households recognize this tradeoff in their personal decisions.

Using data from the Survey of Consumer Finances, we investigate household choices between mortgage prepayments and retirement account contributions. While it is not surprising that some households are not making the right choice, the magnitude of the overall inefficiency is striking. On the margin, $38 \%$ of households who prepay their mortgages could benefit from our proposed arbitrage strategy. Depending on the choice of the investment asset in the TDA, the mean gain from such a reallocation ranges between 11 and 17 cents per dollar of "mis-allocated savings." In the aggregate, correcting this inefficient behavior could save U.S. households as much as 1.5 billion dollars per year. The finding that a significant number of households make substantial mistakes in their financial decisions echoes the conclusions of Campbell (2006).

Although there are numerous potential rational reasons for agents either to prepay the mortgage or not to contribute to their retirement accounts-among them interest rate risks, liquidity and default risks, credit constraints, and fixed costs of participation-we show that, given the nature of the tax arbitrage, those reasons are unlikely to explain simultaneously why households prepay and do not contribute. Hence, it is difficult to identify rational reasons for the inefficient behavior of forgoing the substantial tax benefit.

\footnotetext{
${ }^{2}$ Consider, for example, a Roth account where households pay income tax when they contribute and no more tax is owed upon withdrawal. Also, when tax rates are constant over time, investing in a $401(\mathrm{k})$ account is equivalent to investing in a Roth account.
} 
Rather, these households seem to be influenced by an aversion to take on debt. Empirically, debt aversion and risk aversion explain to some extent the household preference for reducing their debt obligations in spite of incurring considerable monetary losses in the process. The propensity of debt-averse households to forgo such tax arbitrages is related to the findings in Graham (2000), who shows that many corporations forgo substantial tax benefits by holding too little debt.

Our paper is most closely related to the recent literature on the optimal asset location choice which considers the tradeoff between savings in taxable vs. tax-deferred accounts. Dammon, Spatt, and Zhang (2004), Shoven and Sialm (2004), Poterba, Shoven, and Sialm (2004), Huang (2005), and Garlappi and Huang (2006) show theoretically that, in order to maximize the tax benefit of retirement accounts, highly-taxed assets should generally be located in tax-deferred accounts and that lightly-taxed assets should be located in taxable accounts. The actual behavior of individuals investing in taxable and tax-deferred accounts is analyzed by Bodie and Crane (1997), Barber and Odean (2003), Bergstresser and Poterba (2004), and Amromin (2004). These papers find that many households have significant amounts of money in both accounts and that a large proportion of them do not appear to take advantage of the potential benefits of optimal asset location. Similar to this literature, we theoretically compare the tax efficiency of two forms of savings choices, and then document actual household behavior and evaluate the extent of losses relative to the theoretical benchmark. Our main contribution is to introduce mortgage payments as an additional investment option in the tax arbitrage framework. There is also a vast literature on both the retirement savings decisions ${ }^{3}$ and their mortgage choices ${ }^{4}$. To the best of our knowledge, this is the first paper to link these

\footnotetext{
${ }^{3}$ For example, Benartzi and Thaler (2001), Madrian and Shea (2001), Choi, Laibson, Madrian, and Metrick (2002), Cunningham and Engelhardt (2002), Agnew, Balduzzi, and Sunden (2003), Duflo and Saez (2003), Choi, Laibson, and Madrian (2004, 2005), Mitchell, Utkus, and Yang (2005), Duflo, Gale, Liebman, Orszag, and Saez (2006), Huberman and Jiang (2006), and Brown, Liang, and Weisbenner (2006) consider the determinants of individual TDA participation and portfolio choice.

${ }^{4}$ For example, Quigley (2002), Campbell and Cocco (2003), and Hurst and Stafford (2004) study mortgage choices including type of contract, refinancing, and prepayment decisions.
} 
two strands of research by considering retirement contributions and mortgage payments as two alternative forms of household savings decisions.

Our finding is also consistent with the explanation that households may not treat these two forms of saving decisions as substitutes. Hoynes and McFadden (1997) find little substitution between retirement savings and other forms of personal financial asset saving and housing wealth, and Poterba, Venti and Wise (1995) find that even similar saving vehicles like $401(\mathrm{k}) \mathrm{s}$ and IRAs are not close substitutes.

The paper is structured as follows. Section 2 describes the tax-arbitrage strategy in detail and Section 3 discusses the robustness of the tax arbitrage strategy. Section 4 describes the data and Section 5 provides summary statistics for TDA contribution and mortgage payment behavior. Section 6 calculates the cost of choosing the wrong saving strategy. Section 7 looks at possible explanations for why households may forgo the tax arbitrage and Section 8 concludes.

\section{Tax Arbitrage Strategy}

This section describes the tax arbitrage strategy between tax-deferred retirement account contributions and mortgage prepayments. We consider a household whose TDA contributions are less than the statutory maximum and who at the same time makes additional mortgage payments. Households that make additional mortgage payments have effectively chosen to save some of their income through a specific savings channel. We analyze the marginal trade-off between contributing to a TDA and building up home equity to determine whether these households would be better off reallocating their savings.

There exist several different types of retirement accounts. Because of data limitations, we restrict our attention to traditional employer-sponsored TDAs, such as 401(k) and 403(b) plans which allow contributions on a before-tax basis. These contributions 
grow tax-deferred until withdrawal when the household pays taxes both on its original contribution amount and the cumulative investment returns.

The household is assumed to have a constant tax rate $\tau$ over time, and faces a penalty $\kappa_{t}$ on TDA withdrawals at time $t$. Currently, withdrawals by individuals younger than $59 \frac{1}{2}$ years of age generally face a $10 \%$ penalty. Hence, $\kappa_{t}=10 \%$ if $t<59 \frac{1}{2}$ and $\kappa_{t}=0$ otherwise.

To derive our main result, we make the following simplifying assumptions. First, the household has a fixed-rate mortgage with a rate $r_{B}$ and earns a constant rate of return $r_{L}$ on its tax-deferred savings. Second, the household itemizes deductions and can therefore effectively subtract mortgage interest from taxable income. Third, the mortgage has a fixed remaining horizon $T$, which means that the household never defaults or pays off the entire mortgage for moving or refinancing purposes. Fourth, each dollar of prepayment in the current year affects only year $T$ cash flow and reduces the after-tax mortgage payment by $\$\left(1+(1-\tau) r_{B}\right)^{T}$. These assumptions are useful for illustrating the tax arbitrage strategy. We discuss their robustness in Section 3.

Under these assumptions, we propose a simple tax arbitrage strategy where the household makes the following perturbation to its current savings strategy: (i) decreases the mortgage prepayment by one dollar; (ii) contributes an additional

$$
X \equiv \frac{1}{1-\tau-\kappa_{T}}\left(\frac{1+(1-\tau) r_{B}}{1+r_{L}}\right)^{T}
$$

dollars to the tax-deferred account which earns a return of $r_{L}$; (iii) receives an immediate tax credit of $\tau X$ dollars for the additional contribution; and (iv) withdraws $X\left(1+r_{L}\right)^{T}$ dollars from the tax-deferred account in year $T$.

Since the additional contribution $X$ to the tax-deferred account grows to $X\left(1+r_{L}\right)^{T}$ by the end of year $T$, exactly offsetting the withdrawal amount, the new strategy yields the same wealth in the tax-deferred account as the current strategy. Moreover, the total proceeds from the withdrawal are $X\left(1+r_{L}\right)^{T}\left(1-\tau-\kappa_{T}\right)=\left(1+(1-\tau) r_{B}\right)^{T}$, where $\tau$ is the 
tax rate and $\kappa_{T}$ is the penalty upon withdrawal. ${ }^{5}$ At the same time, we have assumed that reducing the current mortgage prepayment by one dollar increases the mortgage obligation by $\left(1+(1-\tau) r_{B}\right)^{T}$ dollars in year $T$. Hence, the withdrawal proceeds exactly offset the additional mortgage liability due to the reduced prepayment of the mortgage loan. Finally, the combination of steps (i)-(iv) implies that the household can walk away with a net profit of $1+\tau X-X$ in the taxable account, which can be consumed immediately. We simplify its expression and term it the "Marginal Arbitrage Profit" (MAP),

$$
M A P \equiv 1+\tau X-X=1-\frac{1-\tau}{1-\tau-\kappa_{T}}\left(\frac{1+(1-\tau) r_{B}}{1+r_{L}}\right)^{T}
$$

For any household, as long as the MAP measure is positive, it is better off following the arbitrage strategy of reducing its prepayment and increasing its TDA contributions. Inspection of equation (2) yields the following intuitive results. First, the arbitrage profit decreases with $r_{B}$ and increases with $r_{L}$. A higher mortgage borrowing rate $r_{B}$ makes it less profitable to stop prepaying, while a higher investment return $r_{L}$ makes it more attractive to invest in the tax-deferred account. Second, the arbitrage benefit increases with the investment horizon $T$ as long as $r_{L}>(1-\tau) r_{B}$, since the money grows tax-deferred for a longer period of time. Finally, this arbitrage strategy is always feasible since it is "self-financed." The only cash outflow implied by the strategy is the additional mortgage payment on the terminal date, which is exactly covered by the future withdrawal from the tax-deferred account. As a result, the household never needs to put in additional money after pocketing the arbitrage profit (MAP).

If households continue to save in the future, this self-financing requirement yields conservative estimates of the arbitrage profit. In particular, if $\kappa_{T}>0$, our strategy requires households to withdraw and pay penalties in order to meet the additional mortgage obligation at time $T$. However, if they can use other funds in their taxable accounts or

\footnotetext{
${ }^{5}$ Note that the household receives $\$\left(1-\tau-\kappa_{T}\right)$ for each dollar withdrawn rather than $(1-\tau)\left(1-\kappa_{T}\right)$ since the penalty is not tax-deductible under the current tax code.
} 
can reduce their future contributions to retirement accounts to satisfy these obligations, they will be able to delay the withdrawal and avoid the penalty. Even when the penalty is zero, delaying the withdrawal allows households to shelter assets from taxation for a longer time period, and hence improves the arbitrage profit.

The MAP further underestimates the benefit of the tax arbitrage strategy if a household does not consume the arbitrage profit immediately. In particular, its current wealth level is increased by the MAP amount. Without reducing its current consumption level or altering any part of its remaining portfolio, it can contribute an additional amount (up to the MAP measure) to its TDA. This additional contribution allows it to further enjoy the benefit of tax-deferred savings. The proposed arbitrage transaction also ignores employer matches and deductibility of TDA contributions from state income taxes, which increase its profitability. ${ }^{6}$

\section{Discussion}

We now discuss the robustness of the tax arbitrage strategy by relaxing the assumptions in the previous section.

\subsection{Stochastic Interest Rates}

In our derivation of the tax arbitrage strategy in Section 2, both the mortgage borrowing rate $\left(r_{B}\right)$ and the tax-deferred investment return $\left(r_{L}\right)$ are assumed to be constant over time. These assumptions work well in the case of a household with a fixed-rate mortgage that never refinances and that buys and holds to maturity Treasury bonds term-matched to the remaining lifetime of its mortgage. While this scenario appears restrictive, we argue below that it likely provides a lower bound on the tax-arbitrage gain.

\footnotetext{
${ }^{6}$ The proposed strategy may also have an indirect benefit of reducing fixed participation costs as discussed by Vissing-Jorgensen (2002) and encouraging equity market participation. Moving mortgage prepayments to employer-sponsored TDA accounts introduces some households to an environment with lower equity participation costs, either because of employer subsidies or simplified investment options.
} 
First, since we restrict our empirical investigation to households with fixed rate mortgages, the assumption of a constant $r_{B}$ is only violated if the mortgage is refinanced in a year $S<T$. As long as the refinancing decision is driven purely by interest rate considerations, the new mortgage rate $r_{B}^{\prime}$ is less than $r_{B}$. For each dollar following the arbitrage strategy today, the mortgage obligation is increased by $\left(1+(1-\tau) r_{B}\right)^{S}$ at time $S$, which grows to $\left(1+(1-\tau) r_{B}\right)^{S}\left(1+(1-\tau) r_{B}^{\prime}\right)^{T-S}$ at time $T$. The arbitrage strategy also yields an extra $X\left(1+r_{L}\right)^{T}$ dollars in TDA, which is equal to $\left(1+(1-\tau) r_{B}\right)^{T}$ by $(1)$, and is higher than the new mortgage obligation. Hence, the arbitrage profit is increased after the refinancing.

Second, while buying-and-holding Treasury bonds is generally feasible in the TDA, it is conservative because interest rates on mortgages at origination tend to be significantly higher than interest rates on Treasury bonds due to prepayment and default risks. To get a better sense of the magnitude of the tax benefit, we maintain the overall risk level of the household portfolio by allowing TDA contributions to be invested in passthrough instruments like a Mortgage-Backed Securities (MBS), which pool individual mortgages. Although there is still a mismatch in the default and prepayment risks between an individual mortgage and an MBS, the MBS is generally less risky due to the benefit of diversification. Moreover, an MBS has a variable maturity due to prepayment and default risks, and its yields vary over time since they are typically sold through mutual funds, which change their asset composition each year. In this setting, households are trading off a fixed mortgage liability for an asset with variable rate of return and maturity, both of which are affected by general movements in interest rates. Yet, we still expect our estimation of the arbitrage profit to be rather conservative, since interest rates have an asymmetric impact on the benefit of the tax arbitrage strategy. When rates increase, households gain since the newly invested amount earns higher rates than the corresponding liability. On the other hand, when rates go down, households are more 
likely to exercise their option to refinance, reducing the downside risk of the arbitrage strategy.

\subsection{Moving-Related Prepayment Risks}

In addition to falling interest rates, households may choose to pay off their entire mortgages early when they sell their existing homes, either because of relocations or simply because of changes in tastes and housing needs.

We have shown that the tax arbitrage benefit can actually be improved if the prepayment is driven purely by interest rate considerations. If, on the other hand, interest rates stay constant over time, the perturbation specified by the arbitrage strategy remains valid for an exogenous moving shock, as long as households are able to roll over their mortgage debt into the new house.

When both the interest rate and moving risks are present, our tax strategy is no longer a risk-free arbitrage. While households are clearly better off if they choose to move when the interest rate goes down, it is also possible that they may need to move when the interest rate goes up and the new mortgage borrowing rate becomes $r_{B}^{\prime}>r_{B}$. As a result, the extra mortgage obligation $\left(1+(1-\tau) r_{B}\right)^{S}\left(1+(1-\tau) r_{B}^{\prime}\right)^{T-S}$ is larger than the potential withdrawal from the tax-deferred saving $\left(1+(1-\tau) r_{B}\right)^{T}$, making it less beneficial to follow our strategy. Of course, in this case, the overall loss from replacing a lower-rate mortgage is substantially greater than the change in the value of the tax strategy. To the extent that moving decisions are somewhat endogenous, households may delay their moving and prepayment decisions when the interest rate environment is not favorable. Thus, it is reasonable to conclude that, although the combination of moving and interest rate risks makes the tax strategy risky, its impact on the expected profitability of the strategy is likely to be small. ${ }^{7}$

\footnotetext{
${ }^{7}$ Quigley(2002) finds that households do, in fact, delay relocating when interest rates are rising.
} 


\subsection{Liquidity Risks}

Our arbitrage strategy also assumes that households never face large liquidity needs that may require them to take out additional home equity loans. At a first glance, paying down a mortgage improves household borrowing capacity almost dollar-for-dollar by enabling higher home equity lines of credit (HELOC). Thus, concerns for future liquidity needs may prompt households to accelerate home equity build-up and forgo implementing the arbitrage strategy. However, a comparison of relative liquidity characteristics of HELOCs and TDAs is far from straightforward.

Most HELOCs are re-evaluated annually and may indeed be cancelled in the event of job loss, making them a poor source of liquidity when it's likely to be needed. On the other hand, most households can borrow up to $50 \%$ of their TDA assets and in worst-case scenarios (e.g. job loss or financial hardship) access TDA assets by paying a $10 \%$ penalty. The tax burden on these hardship withdrawals tends to be low since households will be in relatively low tax brackets under these circumstances.

Since the arbitrage strategy simply reallocates assets between accounts, its effect on household's liquidity is summarized by the difference in transaction costs. TDA withdrawal penalties are likely costlier than the spread on home equity loans. ${ }^{8}$ Still, as long as the probability $q$ of liquidity event is low enough, the ex-ante expected cost $(q \times 10 \%)$ is small relative to the expected arbitrage profit, which is in the range of $11-17 \%$ (as shown in Section 6).

Another reason that liquidity risks prove to be less relevant as a rational explanation for forgoing the tax arbitrage profit is that fluctuations in future housing prices make mortgage prepayments less effective as a mean to provide liquidity when needed. If house prices appreciate significantly over time, then the amount of home equity is likely to be sufficient to meet any liquidity needs even without mortgage prepayment. No

\footnotetext{
${ }^{8}$ In our data set, the home equity loan has a mean interest rate of $9.3 \%$, while the same household has an average mortgage rate of $7.6 \%$.
} 
withdrawal from the tax-deferred account is necessary. On the other hand, if house prices fall drastically to wipe out most of the equity, it is unlikely that the household may be able to take out additional home equity loans, even if it has been diligently prepaying the mortgage. In this case, had the household followed our tax strategy to save in the tax-deferred account instead of prepaying the mortgage, the funds would still be available for liquidity-related withdrawals. Hence, our strategy of saving in the tax-deferred account has the additional benefit of providing a good hedge against the combination of housing price risk and liquidity risk.

\subsection{Default Risks}

Default risks are extraordinary liquidity events in the future that may force households to default on mortgage payments and hence lose their houses. A household may prefer to pay off its mortgage before saving in retirement accounts in order to reduce the risk of ever losing the house. Although reasonable on the surface, we argue that this argument does not justify foregoing the tax-arbitrage either.

First, following the tax-arbitrage strategy is unlikely to increase the probability of default for a household. Consider the case when the large liquidity event happens after the household would have paid off its mortgage had it followed the accelerated payment schedule. By construction, our tax arbitrage strategy is "self-financed" in the sense that once the original plan would have paid off the mortgage, households rely solely on the withdrawal from the tax-deferred account to pay for the remaining mortgage. Hence, following the arbitrage strategy does not cause extra defaults in this case.

If, on the other hand, the liquidity event happens before the household would have paid off its mortgage even under the accelerated schedule, borrowing or withdrawing from the tax-deferred account is at least as effective as (if not more than, considering housing price risks) prepaying the mortgage in meeting this liquidity need. Again, following the arbitrage strategy does not increase the default risk. 
Second, in the unfortunate event of personal bankruptcy, households are generally better off had they followed the tax-arbitrage. As a federal policy, employer-sponsored retirement savings are exempt from personal bankruptcy. ${ }^{9}$ On the other hand, homestead exemptions vary by state, with some states (e.g. Florida) allowing nearly unlimited exemptions and others (e.g. Pennsylvania) only a token amount. In the event of large liquidity shocks, our tax arbitrage strategy provides households with the additional option of defaulting on the house and claiming bankruptcy while at the same time retaining their extra TDA savings. While the psychological costs of losing a house may be large, this free option increases the benefit of the tax arbitrage strategy from a pure monetary point of view, especially for residents of states with stringent homestead exemptions. ${ }^{10}$

\subsection{Tax Environments}

We have also made several simplifying assumptions regarding tax environments, the most significant one being the constant tax rate over time. ${ }^{11}$ This assumption excludes the possibilities of either changing tax laws or changing tax brackets over a household's lifetime. Although it is hard to predict the direction of tax law changes, the assumption of a constant tax rate is likely conservative for estimating the tax benefits of our arbitrage strategy. The tax rate for a given household is generally lower during retirement since the taxable income is often lower. According to the 1995-2001 SCF data, 41\% of households are in the top four tax brackets (i.e., at or above 28\%) before retirement while only $18 \%$ of households are in these top brackets after retirement. ${ }^{12}$ The household can also optimally time the withdrawals from its retirement account to minimize the effective tax

\footnotetext{
${ }^{9}$ Since the passage of the Bankruptcy Abuse Prevention and Consumer Protection Act in April 2005, all IRA assets are fully protected from creditors in the event of bankruptcy. Prior to that, the amount of IRA assets exempt from bankruptcy estate varied by state.

${ }^{10}$ See, for example, White (1998) and Fay, Hurst, and White (2002) for a discussion of the household bankruptcy decision.

${ }^{11}$ See, for example, Sialm (2006) for a discussion of historical tax rates on investment income between 1926-2004.

${ }^{12}$ Households are assumed to be retired if they receive positive Social Security, pension, or disability income in the corresponding years.
} 
burden. Hence, tax-deductible contributions are made when rates are relatively high and taxable withdrawals are made when rates are relatively low, increasing the tax arbitrage profit. To gauge sensitivity of the arbitrage strategy to changes in tax rates, we evaluate a number of alternative tax scenarios in Section 6.3.

In this section we have argued that relaxing the assumptions of the illustrative arbitrage example is unlikely to eliminate gains from the strategy. However, whether households use similar reasoning in practice is an open question. For example, they may have a different perception of relative liquidity of the two savings choices, or not be aware of differences in their bankruptcy treatment. We return to this question in our empirical analysis of Section 7.

\section{Data Sources}

We use the 1995, 1998, and 2001 Surveys of Consumer Finances (SCF) to analyze the actual savings behavior of households with mortgage debt and with the opportunity to save in employer-sponsored tax-deferred retirement accounts. The surveys are conducted by the Board of Governors of the Federal Reserve System and cover a substantial cross-section of U.S. households. They collect data on many aspects of households' financial situation-their financial, real estate, and pension assets, portfolio composition, availability and price of credit, and sources of earnings. ${ }^{13}$

The surveys over-sample wealthy households, since these households own a disproportionate fraction of financial assets. We use a set of sampling weights from the SCF to compute distributions of survey variables in the population. Unless otherwise noted, all descriptive statistics utilize population weights.

Since our analysis focuses on evaluating the trade-off between saving in retirement accounts and through additional mortgage payments, SCF data on real estate holdings, financing, and on tax-deferred savings choices are of particular interest. For each house-

\footnotetext{
${ }^{13}$ See Kennickell and Starr-McCluer (1994) for a description of the SCF data set.
} 
hold in the sample, the SCF collects exhaustive information on home ownership status and financing characteristics. Thus, we know whether a household owns its home and if so, whether it still has an outstanding mortgage. We know the key characteristics of mortgages such as their current interest rate, mortgage term, remaining as well as original balance, and whether a mortgage is an adjustable rate or a balloon mortgage. Moreover, we know whether a household is actively prepaying its mortgage, sticking to the original payment schedule, or falling behind scheduled payments.

We distinguish between two different methods of prepayments: discretionary and those due to short mortgages, which are defined as mortgages with a term of less than 30 years. Discretionary prepayments occur if households make payments in addition to their required mortgage obligations at regular or irregular intervals. We identify discretionary prepayments from household responses to the SCF question on whether they are ahead, behind, or on time with their mortgage payments. ${ }^{14}$

Unfortunately, the SCF does not ask prepaying households for the exact amount or the frequency of discretionary prepayments. However, they are asked for an expected date of full repayment. By contrasting this date with the original mortgage term and assuming a constant prepayment schedule, we are able to estimate the additional annual mortgage payments. ${ }^{15}$ We define prepayments due to short mortgages as the difference between the required payment on the existing mortgage and a required payment on a hypothetical 30-year mortgage that the household could have taken out on the origination date. Specifically, we derive the average mortgage rates from the Freddie Mac series of the average initial contract rate on new commitments for 15- and 30-year conventional fixed-rate mortgages with $80 \%$ loan-to-value ratios. For each household with a 15 -year

\footnotetext{
${ }^{14}$ Using this method, we classify about $16 \%$ of households with 30 -year fixed-rate mortgages as "discretionary prepayers." This number is very similar to the $14 \%$ incidence of accelerated repayments reported by $\mathrm{Fu}$ et al. (1997) on the basis of administrative records of Citibank mortgage holders between 1995 and 1997.

${ }^{15}$ We also investigate alternative discretionary prepayment measures, which are based on the comparison of the reported current mortgage balance with the balance expected if only required payments were made. If the former is smaller, a household is effectively ahead of its mortgage repayment schedule. Our results remain qualitatively similar if we use this alternative prepayment measure.
} 
mortgage, for example, we compute the difference between its mortgage rate and the average rate on 15-year mortgages taken on the same date. Assuming that this quality spread is independent of the mortgage term, we can add it to the average 30-year mortgage rate to construct the rate on a hypothetical 30-year mortgage. Hence, our calculation takes into account the slope of the yield curve that usually implies a lower 15-year mortgage rate than a 30 -year rate.

In order to evaluate possible benefits of saving in a TDA, we need to identify TDAeligible households and estimate the extent to which they can increase their TDA contributions. An accurate measure of eligibility can be constructed from a number of sequential responses to questions about features of employment-related pension coverage. We follow the methodology in Pence (2001) to identify households that are eligible for (but don’t necessarily participate in) high-limit employer-sponsored defined contribution retirement plans.

Household contributions to employer-sponsored TDA plans are reported separately for each household member. However, annual limits on household TDA contributions are less straightforward, as they are determined by the individual's wage income and employer policies. In 2001, each TDA participant was limited to a before-tax contribution of $\$ 10,500$ (IRC 402(g) limit). In addition, the sum of employee and employer contributions is subject to an additional restriction of the lesser of $\$ 35,000$ or $25 \%$ of compensation (IRC 415(c) limit). Moreover, many plans impose their own limits on employee contributions in order to make it easier to pass non-discrimination tests. Since the SCF has no information on employer-specific TDA plan features, we choose a conservative approach and define the contribution limit in 2001 for each household member as the lesser of $\$ 10,500$ or $10 \%$ of their reported wages. For 1995 and 1998, we use the corresponding IRC 402(g) limits, which are $\$ 9,240$ and $\$ 10,000$, respectively. Next, we compute the "TDA contribution gap" by differencing the actual contribution and 
the imputed limit for each eligible household member. Summing up these gaps for all household members gives us a measure of the extent to which a given household can increase its TDA contributions.

A significant number of SCF respondents are self-employed and, under the current tax code, they have the right to open IRA-type accounts with high contribution limits and nearly unrestricted investment choices. ${ }^{16}$ However, since the actual TDA contributions by the self-employed are unknown, we choose to restrict the definition of eligibility to households with at least one member that can participate in an employer-sponsored plan. We also ignore the role of IRAs in defining TDA eligibility. Although IRAs are broadly available, their contribution limits are small and the SCF has no data on actual IRA contributions. Both of these choices are conservative as they limit the universe of households that can potentially benefit from modifying their savings choices and are likely to bias the contribution gaps towards zero.

For investments in the TDA we consider two scenarios in which households hold either mortgage-backed securities (MBS) or Treasury bonds with the same maturity as the remaining mortgage horizon. The yield on Treasury bonds for various maturities is linearly interpolated between the 10-year yield and the 30-year yield reported by Bloomberg for each of the three survey years. The MBS returns of different maturity are also linearly interpolated using yields on 15- and 30-year current coupon agency MBS (Fannie Mae and Freddie Mac) as reported by Bloomberg. Note that the average yield on Treasury bonds is substantially lower than the average mortgage rate in our sample, primarily because Treasury bonds do not have default and prepayment risks as individual mortgages. The average investment rate on MBS assets is also lower than the average mortgage borrowing rate, due to the transaction costs of processing mortgages and constructing MBS assets. As discussed in Section 3.1, investing in Treasury securities

\footnotetext{
${ }^{16}$ There are several such accounts - Keogh, SEP-IRA, etc. - all of which have high contribution limits. For example, Keogh plans allow one to save up to $\$ 40,000$ per year in combined employee and employer contributions.
} 
provides a lower bound on the tax-arbitrage profit, while investing in MBS provides a better estimate of the magnitude of the tax benefit. We do not consider additional asset classes (e.g. equities) in our main results, because we do not want to change the aggregate risk level of the portfolio.

In addition to the variables that describe mortgage characteristics and TDA savings choices, we include a number of controls that reflect household wealth, income, demographics, measures of financial savvy, liquidity constraints, self-reported reasons for savings, and levels of risk and debt aversion. All of these variables are available in the SCF. Finally, our estimates of households marginal tax rates (MTR) are derived from TAXSIM calculations based on SCF income data. ${ }^{17}$

\section{Summary Statistics}

Homeowners with mortgage debt face the decision of whether to save first by repaying their mortgage early or by contributing to a tax-deferred retirement account. As discussed in Section 2, this decision depends on numerous individual characteristics, such as the mortgage interest rate, the investment opportunities, the effective tax rate, the saving horizon, and additional liquidity and borrowing constraints facing a household. In this section we divide households into distinct groups on the basis of their TDA and mortgage prepayment decisions and provide a high-level comparison of key characteristics of these groups to set the stage for the subsequent analysis of their choices

\subsection{Household Characteristics by Eligibility and Home Own- ership}

Table 1 summarizes the characteristics of households according to their savings opportunities. The three columns display characteristics of all households (column 1), of

\footnotetext{
${ }^{17}$ We are very grateful to Kevin Moore and Dan Feenberg for computing these marginal tax rates. Additional information on this microsimulation model can be found in Feenberg and Coutts (1993).
} 
households that are eligible to contribute to employer-sponsored retirement accounts (column 2), and of those eligible households that own houses and have fixed rate mortgage debt (column 3). Our complete sample over the three survey years includes 13,046 observations that are based on an average of 102.7 million households per year using the population weights given in the SCF. Slightly less than half of the households are eligible to contribute to an employer-sponsored TDA. Slightly less than half of these eligible households have a fixed-rate mortgage on their home. Thus, the average sample of households that face the TDA-mortgage prepayment tradeoff contains 22.8 million households per survey.

To describe the distribution of household characteristics in our paper, we summarize the mean and the inter-quartile ranges (IQR) of the corresponding variables. Households that are eligible to contribute to an employer-sponsored retirement account tend to be younger primarily because retired households do not have the opportunity to save in retirement accounts. Eligible households are better educated than non-eligible households: $43.4 \%$ of eligible households have a college degree, while only $24.0 \%$ of non-eligible households have a college degree. This difference occurs because retirement plans tend to be more prevalent in companies where a large fraction of employees are professionals. Eligible households receive significantly higher incomes and are in higher tax brackets than non-eligible households.

The income and wealth distribution is highly skewed to the right, resulting in significantly higher means than medians. For example, the mean normal household income level for the three survey years sample is $\$ 54,211$, while the median income level is just $\$ 35,977$. The differences are much more pronounced for wealth levels. The mean household net worth in the SCF sample is $\$ 280,689$, which exceeds the 75 percentile of $\$ 205,600$. These results confirm the well-known observation that the aggregate wealth is concentrated among a relatively small fraction of the population. ${ }^{18}$

\footnotetext{
${ }^{18}$ See Poterba (2000) for a description of the wealth concentration in the U.S.
} 
Comparing the second and the third columns indicates that eligible homeowners with outstanding mortgage debt tend to have higher income and wealth levels than all eligible households. The following sections focus on this last group of households which have the choice of saving by building up home equity or retirement assets. ${ }^{19}$

In unreported analysis, we have divided our sample into the three waves of the Survey of Consumer Finances. Most household characteristics and our main results remain the same over the time periods. So we do not differentiate among the survey years in the remainder of the paper.

\subsection{Household Characteristics by Saving Behavior}

We sort the sample of eligible households with fixed-rate mortgage debt into four different groups according to their TDA contribution and mortgage prepayment behavior. Table 2 summarizes the characteristics of households for these four groups. The first sorting criterion depends on the contribution to the employer-provided retirement account. We observe that $34.6 \%$ of eligible households with fixed-rate mortgages (7.9 million households per year) do not contribute at all. To economize on space, we average over prepaying and non-prepaying households to report household characteristics by their contribution decisions. On average, non-contributing households could contribute an additional $\$ 5,640$ to their TDAs, while contributing households could increase their contributions further by $\$ 2,814$ before reaching the contribution limit.

These results indicate that many households do not take full advantage of the taxqualified retirement savings opportunities. These households might relinquish substantial tax benefits and matching contributions of their employers. This fact is particularly puzzling as many of these households own substantial financial assets, which they could effectively transfer to their retirement accounts. Non-contributing households in our

\footnotetext{
${ }^{19}$ In our sample, $89 \%$ of households with mortgage debt have a fixed-rate mortgage. We focus on fixed-rate mortgages because we do not know the exact adjustment pattern and frequency for adjustablerate mortgages. However, households using adjustable-rate mortgages can also use similar arbitrage strategies as the ones described in our paper if they use floating-rate bonds instead of fixed-rate bonds.
} 
sample own, on average, taxable financial assets with a total value of $\$ 73,375$. This average financial wealth level is skewed to the right as a small number of households own very large portfolios of liquid financial assets. However, $53.9 \%$ of these non-contributing households own liquid financial assets exceeding $\$ 10,000$.

The second sorting criterion depends on whether a household accelerates its mortgage payoff either by making additional discretionary payments or by choosing a short-term mortgage. We quantify both types of prepayments using the methodology described in the preceding section. Aggregating over different contribution groups, we find that $46.1 \%$ of eligible households with fixed-rate mortgages (10.5 million households) accelerate their payments. Prepaying households make, on average, total prepayments of $\$ 3,140$ per year, where average discretionary prepayments amount to $\$ 1,482$ and additional prepayments due to short-term mortgages amount to $\$ 1,658$.

Combining the findings between the mortgage prepayment and the non-contribution decisions, we have identified a substantial group of households that face the tradeoff between TDA contribution and mortgage prepayments. We can utilize the arguments in Sections 2-3 to check whether they are acting efficiently. It is particularly interesting to compare the characteristics of the households in columns two (prepay and not contribute) and three (contribute and not prepay) of Table 2. These households tend to save similar amounts through prepayments and retirement account contributions. However, the characteristics of these two groups of households differ substantially. As shown in Panel B, the prepayers tend to be in better financial shape than the partial contributors, which makes liquidity and other concerns identified in Section 3 less relevant and their decision to forgo the tax arbitrage all the more puzzling.

Panel C summarizes the mortgage characteristics of the households. The mortgage rate tends to be slightly lower for prepayers, because some prepayers have short-term mortgages that tend to have lower interest rates. Not surprisingly, the prepayers tend 
to have lower loan-to-value ratios, because many of these households also prepayed their mortgages in the past, which reduced their outstanding balance.

Finally, Panel D provides information on household credit card balances. While there exists a statistically significant difference in the share of prepayer and non-prepayer households with revolving balances, credit card debt is still quite common among prepayers. Among households in the second column (prepay and not contribute) that carry credit card debt, the median balance is $\$ 2,000$ and the median annual interest rate is 12 percent. These households would clearly benefit from curtailing prepayment of lower-interest (and often tax-deductible) mortgage debt and using the funds to pay off their credit cards. They could do even better by using some of their highly liquid funds invested in low-yielding assets like savings and money market accounts. This puzzle, highlighted by Gross and Souleles (2002) is intriguing, but it remains outside the scope of this paper. ${ }^{20}$

\section{Gains from the Tax Arbitrage Strategy}

This section computes the gains that households may achieve by following the proper trade-off between mortgage prepayments and contributions to tax-deferred accounts. These computations are normative in nature, as they identify households that make "suboptimal" choices and impute the magnitudes of likely losses. We show that many households make costly errors with respect to two of their most common financial decisions-saving in a tax-deferred account and building equity in their home.

\subsection{Marginal Benefits of The Tax-Arbitrage Strategy}

The data in Table 2 shows that many households face the TDA contribution-prepayment tradeoff. As discussed in Section 2, whether these households could be made better off

\footnotetext{
${ }^{20}$ See Haliassos and Reiter (2005) for a novel solution to this puzzle based on intra-household decision making with heterogeneous preferences (the "accountant-shopper" framework).
} 
by decreasing their prepayments and increasing their contributions to the retirement account depends on households characteristics like available mortgage rate, investment opportunities, effective tax burden, time horizon, and so on. While the reshuffling of savings choices may not be optimal for all households, we can estimate the fraction of households that would be better off by changing their saving strategies.

We start by computing the marginal tradeoffs between accelerating mortgage payments and saving for retirement in the tax-deferred account. This tradeoff is given by the MAP measure as derived in equation (2). We use the actual mortgage rates of the households for $r_{B}$ and the current interest rates on mortgage-backed securities or Treasury bonds for the investment rates $r_{L}$, as discussed in Section 4. Mortgage interest is assumed to be deductible at the tax rate $\tau$ only if the households currently itemize deductions. For non-itemizing households we assume that mortgage interest is not deductible. The investment horizon $T$ equals the remaining maturity of the current mortgage. Finally, TDA withdrawals face a penalty of $10 \%$ if the retirement account holder is younger than $59 \frac{1}{2}$ years.

Table 3 summarizes the measure of MAP for households in our sample. Panel A assumes that the retirement account is invested in MBS with a remaining maturity equal to that of the mortgage. We demonstrate that a significant share of prepaying households would benefit from our proposed tax arbitrage by transferring the prepayments to mortgage-backed securities in their retirement accounts. For example, $43.4 \%$ of eligible households that make prepayments and do not contribute exhibit positive arbitrage gains. The mean arbitrage gain from switching $\$ 100$ from a mortgage prepayment to a retirement account amounts to $\$ 17.20$ for this group. The distribution of the benefits is relatively broad and the inter-quartile range varies between 7.7 and $23.7 \%$. We can interpret the MAP as the extra return that households can earn on their savings by simply choosing the proper saving channel. The $17.20 \%$ is the present value of extra 
future returns, which amounts to more than $1 \%$ of extra return per year given the average horizon of households of 17 years in our sample. Considering the difficulty for most mutual funds to generate this level of abnormal performance, our return from the simply tax-arbitrage strategy is rather impressive.

We obtain very similar results for households that make discretionary prepayments and contribute to their employer-sponsored retirement accounts. Note, however, that of the 3.5 million households with positive MAPs in this group, only 2.5 million that are not bound by the contribution limit would benefit from the proposed tax arbitrage. The mean marginal gain for such households equals $16.6 \%$.

Panel B summarizes the distribution of the tax benefits if the retirement account is invested in Treasury bonds instead. As discussed in Section 3.1, this conservative approach provides a lower bound on the tax benefit. It is comforting that we still obtain a MAP of about $11 \%$ for those households that prepay.

\subsection{Total Benefits of The Tax-Arbitrage Strategy}

To quantify the Total Arbitrage Profit (TAP) for each household, we multiply the Marginal Arbitrage Profit (MAP) by the minimum of the total prepayment and the contribution gap:

$$
T A P_{i}=M A P_{i} \times \min \left(\text { Prepayment }_{i}, \text { ContrGap }_{i}\right)
$$

The TAP is positive only if the household has a positive MAP and if it is prepaying and not contributing the maximum possible to the TDA.

In Table 3, we show that, on average, prepaying households that do not contribute forgo a TAP of $\$ 394$ per year. The TAP measures are, on average, slightly smaller for prepaying households that already contribute to a retirement account. Overall, an average contributing household forgoes a TAP amounting to $\$ 375$ per year. With a total of about 4 million households experiencing a positive TAP, we calculate that households 
can gain about 1.5 billion dollars in tax benefits by following our tax strategy.

Households do not have an option to replace a short-term mortgage with a longterm mortgage without refinancing. On the other hand, it is relatively easy to simply discontinue the discretionary mortgage prepayments. Therefore, we also report the TAP separately between the gains that occur from discretionary prepayments and short-term mortgages. Since a small number of households prepay in both manners and face binding constraints, the total TAP is slightly smaller than the sum of the two individual TAPs. We find that the average TAP from discretionary prepayments is larger than the TAP from short-term mortgages.

In Panel B, we show that even under the most conservative assumption of investing in Treasury bonds in TDA, we have 2.5 million households with positive TAPs, leaving an aggregate of $\$ 637$ million per year on the table by prepaying and not contributing to the maximum extent.

\subsection{Alternative Scenarios}

In this subsection, we calculate the forgone arbitrage gains using alternative assumptions about future tax rates, employer matches, withdrawal penalties, and state taxes.

Our calculation of MAP in (2) has assumed a constant tax rate over time. As discussed in Section 3.5, tax rates can change over time either due to frequent tax reforms or due to the change in taxable income throughout the lifetime of a household, which generally put households in lower tax brackets during retirement. A higher tax rate in the future has two effects on the arbitrage profit: First, the mortgage interest payments receive higher tax deduction over time, which improves the arbitrage profit. Second, the withdrawal from the TDA on the terminal date is worth less after-tax, which reduces the arbitrage profit. Hence, the least favorable tax situation for a household is an increase in the tax rate only on the terminal date.

In Table 4, we report the forgone arbitrage profit for several alternative scenarios 
in which tax rates at withdrawal $(T)$ and during the remaining mortgage term $(T-t)$ are allowed to vary from the current reported marginal tax rates. The first row repeats the forgone arbitrage profits and the number of affected households for our base-case scenario described in Table 3. We start by considering several scenarios in which the marginal tax rate changes only at the time of withdrawal, which yields more extreme results. ${ }^{21}$

Rows (2) and (3) assume that marginal tax rates will increase or decrease by $25 \%$ for all tax brackets at time $T$. For example, the marginal tax rate of a household in the $28 \%$ tax bracket would either increase to $35 \%$ or decrease to $21 \%$. A future tax increase reduces the number of households with positive MAPs from 3.9 million to 2.7 million and reduces the average MAPs slightly. Thus, the aggregate forgone tax benefit decreases from $\$ 1.52$ billion to $\$ 0.86$ billion. On the other hand, a reduction in the tax rates at withdrawal would increase the aggregate subsidy to $\$ 2.36$ billion. A more extreme $50 \%$ increase in the tax rates across the board will reduce the number of affected households to 1.5 million. Even in this worst-case tax scenario for our strategy, however, the forgone tax benefit amounts to about $\$ 400$ million.

The following four scenarios (rows (6)-(9)), change the progressivity of the tax system by increasing or decreasing the tax rates of only the top three tax brackets. This setup is similar in spirit to the 1993 tax increase, which was motivated in part by mounting budgetary pressures. Furthermore, the scenarios in rows (8) and (9) implement the change in tax rates five years from the survey date. In the case of tax increases (8), the negative effect of higher taxes at withdrawal is now counterbalanced by the greater attractiveness of the mortgage interest deduction in the intervening years (from $t+5$ to $T)$. On net, the total forgone tax benefit declines to $\$ 1.37$ billion.

Many employers provide matching TDA contributions. With matches, a household

\footnotetext{
${ }^{21}$ Admittedly, it is difficult to imagine implementation of such tax reform, since it would affect different households at different points in time. We also consider a more realistic situation in which the tax rate changes five years from the survey date and remain fixed until the terminal date.
} 
can finance the arbitrage strategy by contributing less of each dollar saved from mortgage repayment. Assuming an employer match of $\$ m$ for each $\$ 1$ in contributions, the amount required to repay the extra mortgage balance at $T$ decreases from $X$, defined in (1), to $X^{\prime}=X /(1+m)$, resulting in a new MAP of $1-(1-\tau) X^{\prime}$, which is higher than the existing MAP in (2). However, matches are nearly always capped at a certain percentage of salary and both the cap and match vary across employers. Since the SCF only reports the product of these two terms (i.e. the total employer match), we assume a common match rate of 0.5 applied to contributions up to $6 \%$ of total salary. This matching schedule mimics the most common practice of U.S. employers (Engelhardt and Kumar, 2006). Row (10) of Table 4 shows this scenario applied to households that report having an employer match component in their TDA. Contributions beyond the assumed matching cap are valued using the MAP measure in (2).

As conjectured, allowing employer matching substantially increases the attractiveness of the arbitrage strategy. The mean marginal gain from a re-allocated dollar in mortgage prepayment jumps to $38 \%$, and the aggregate subsidy value increases to $\$ 2.64$ billion. The average gain rises more modestly, as many of the extra 1.7 million households with positive MAP values find it optimal to contribute only up to the matching limit which restricts their dollar gains from following the strategy.

The table also reports scenarios that allow deductibility of TDA contributions and mortgage interest payments from state taxes and eliminate early withdrawal penalties. In particular, the gains would be significantly higher if households avoid withdrawing TDA funds early to eliminate the $10 \%$ early withdrawal penalty. Since the public SCF data do not include information on the households' state of domicile, we do not include state taxes in our computations. However, row (12) evaluates a hypothetical case of mortgage interest and TDA deductions from a uniform 5\% state tax. Doing so increases the aggregate forgone tax benefit to $\$ 1.93$ billion. 


\subsection{Characteristics of Losers and Winners from Arbitrage}

To set the stage for further analysis on why households leave money on the table, we summarize the characteristics of households that benefit or lose from our proposed arbitrage in Table 5. Panel A summarizes the main determinants of the gains of the proposed arbitrage. Households that gain from our proposed arbitrage tend to be slightly older, primarily because older households are less likely to face the $10 \%$ early withdrawal penalty. It is not surprising that the winners have lower mortgage interest rates and lower mortgage spreads than the losers. Finally, arbitrage winners tend to be in higher tax brackets than arbitrage losers.

Panel B summarizes the wealth characteristics of winners and losers. The average net worth of the households that currently do not contribute to an employer-sponsored retirement account and that would gain from our proposed arbitrage amounts to $\$ 551,529$ and more than $75 \%$ of these households have a total net worth exceeding $\$ 100,000$. A significant fraction of this net worth is held in liquid non-retirement assets and in home equity. The average non-retirement liquid wealth equals $\$ 142,063$. Moreover, only $10 \%$ of these households have current loan-to-value ratios exceeding $80 \%$, which might result in additional mortgage insurance premia. We obtain very similar results if we focus on households that make partial contributions to their retirement accounts. This indicates that it is unlikely that a large fraction of the winners face substantial liquidity constraints, which would induce them to save by paying down their mortgage instead of saving in a retirement account.

\section{$7 \quad$ An Empirical Analysis of Prepayment and Retire- ment Saving Decisions}

As shown in the preceding sections, a significant number of households fail to make wealth-maximizing decisions with respect to two of their most significant assets-housing 
wealth and tax-deferred retirement accounts. In particular, we showed that when faced with the trade-off between paying off an extra dollar of mortgage and saving that dollar in a tax-deferred retirement account, households often choose an inferior strategy leading to large aggregate losses.

Our goal in this section is to provide some explanation for this seemingly inefficient behavior. We focus on four non-exclusive possibilities-(a) households are constrained by their liquidity and consumption needs; (b) information required for making a proper choice is limited or costly; (c) household decisions are influenced by certain institutional features, such as private mortgage insurance (PMI) and bankruptcy law; ${ }^{22}$ and (d) household choices are distorted by specific preferences over the form of saving and perceived differences in risk and liquidity characteristics between the two savings habitats. A particular form of preferences in (d) is referred to as "debt aversion." For example, debt-averse households may find mortgage repayment that directly reduces their debt a more appealing savings choice, even though it may result in lower net worth than TDA contributions.

The intuition for each of these classes of explanations is straightforward. Not having enough current resources may curtail the ability of some households to make decisions on the infra-marginal level. Moreover, liquidity-constrained households would put greater emphasis on accessibility of saved assets, and would thus favor savings habitats that they perceive as more liquid. Limited information may preclude an objective cost-benefit analysis of the tradeoff.

On the other hand, choosing to forgo the arbitrage strategy may be a rational response to certain institutional factors. As described in Section 3.4, households in high homestead-exemption states may choose to build up their home equity as a means to shelter assets in the event of bankruptcy. Similarly, households may be accelerating

\footnotetext{
${ }^{22} \mathrm{PMI}$ is mortgage guarantee insurance offered by the private insurance market which protects the lender from a loss in the event of default. Lenders typically require PMI on mortgages that have loan-to-value ratios of greater than 80 percent.
} 
repayment to bring their loan-to-value ratios below the 80 percent threshold, thereby obtaining an option to eliminate PMI payments.

Turning to preferences, more risk-averse households may choose to forgo an increase in expected wealth since the proposed exchange of a mortgage dollar for a TDA dollar is risky when the latter is invested in, say, an MBS fund. Finally, being motivated by a "socially acceptable" savings goal like debt-free home ownership may eliminate other savings vehicles from the set of alternative investment choices.

Our empirical analysis is structured as follows. First, we consider the determinants of each of the savings choices - having a short maturity mortgage, making discretionary mortgage prepayments, and contributing to TDA - and analyze whether these choices are made jointly. We next look at the relative preference for retirement savings, by analyzing the share of total TDA-mortgage savings that is attributable to TDA contributions. In particular, we test the hypothesis that households understand the tradeoff between these two forms of savings and tilt their choice towards TDA contributions when it is more beneficial to do so (i.e., when MAP is higher). We further test whether the hypothesized relationship between MAP and TDA-mortgage savings decision varies with household preferences and knowledge.

\subsection{Variable Definitions}

Throughout this section, we will be using a vector of explanatory variables based on the discussion in the preceding subsection. Taking the choice to hold a short mortgage as an example, we estimate the following probit regression:

$$
\begin{aligned}
& \text { ShortMortgage }_{i}=\beta_{1} \text { MAPComponents }_{i}+\beta_{2} \text { Liq.Constraints }_{i}+\beta_{3} \text { Information }_{i}(4) \\
& +\beta_{4} \text { Institutions }_{i}+\beta_{5} \text { Preferences }_{i}+\beta_{6} \text { EmployerMatch }_{i}+\beta_{7} \text { Demographics }_{i}+u_{i}
\end{aligned}
$$

Regressors that make up the vector of MAP components include (a) the spread between the existing mortgage rate and the MBS rate at the time of the survey, in- 
terpolated over the remaining mortgage term $\left(r_{B}-r_{L}\right)$, (b) the federal tax bracket in the year preceding the survey, and (c) an indicator variable for households that itemize deductions.

We define liquidity constraints by combining information from several survey questions. Liquidity-constrained households are defined as those that satisfy at least one of the following conditions: (i) they were turned down for credit at least once during the past five years, (ii) were not able to obtain this credit later or were discouraged from applying again, or (iii) have credit card balances in excess of $75 \%$ of their total credit card borrowing limit. Household wealth is another indicator of liquidity constraints, measured by the logarithm of household net worth.

We use two binary variables to gauge how easy it is to acquire and to analyze information necessary for making financial decisions. The first is a simple indicator variable for having a college degree. The second takes on a value of one for households that consult a professional in "making savings and investment decisions". The list of suitably knowledgeable professionals includes accountants, bankers, brokers, and financial planners. About $49 \%$ of households in our sample relied on advice from such professionals.

Residence in a high homestead exemption state and presence of PMI serve to describe the institutional setting. About 19\% of households in our sample reside in "High Homestead Exemption"states (defined as states with a statutory homestead exemption of at least $\$ 100,000)$, and about $22 \%$ report carrying PMI. ${ }^{23}$

One of the measures of preference heterogeneity is the self-reported willingness to take on financial risk which ranges from 1 to 4 , with the value of 4 indicating "unwillingness to take any financial risks." Our measure of household tolerance for debt is based on reported behavior with respect to paying off credit card debt. This binary variable is set

\footnotetext{
${ }^{23}$ High Homestead Exemption states include FL, IA, KS, OK, SD, and TX, which have no limits, and AZ, MA, MN, NV, and RI, which have exemptions above $\$ 100,000$. Restricting "high exemption" states to those with no limits does not affect the results. We are indebted to Kevin Moore of the Board of Governors for estimating regression specifications with state-specific variables using internal SCF data.
} 
to one for those that report paying off their balances in full "always or almost always". Arguably, such payment behavior reflects not only the household's ability to pay but also its determination to restrict its spending to what it can afford. Consequently, we interpret this variable as an indicator of debt aversion.

The vector of regressors is rounded out by a measure of attractiveness of TDA contributions and simple demographics. We would expect the magnitude of employer match to affect mortgage prepayment choice only if this form of savings is a substitute or a complement of TDA contributions. ${ }^{24}$ The vector of demographic characteristics contains the number of children in the household, as well as age and marital status. Finally, we also include survey year and mortgage origination year dummies, where the latter control for exogenous changes in the structure of mortgage markets. Table 6 contains the moments and the pairwise correlations between the various explanatory variables.

\subsection{What Influences Prepayment and Contribution Behavior?}

From the outset, we limit the sample to home owners with outstanding fixed-rate mortgages who are eligible to participate in employer-sponsored tax-deferred plans. These households face an active choice between prepayment and TDA contributions.

Table 7 presents the results of estimating probit regressions (4) for each of the three savings choices separately. The leftmost column shows the estimated marginal effects of the regressors on the choice of a short-maturity mortgage. We find that variables pointing to a higher MAP are associated with a lower likelihood of prepayment, as suggested by the argument in Section 2. In particular, the likelihood of holding a short mortgage decreases with the borrowing-lending spread. A lower spread implies that it is more attractive to decrease monthly mortgage payments by switching to a 30-year mortgage and to invest the difference in TDA. Of the two tax variables, itemization (which is

\footnotetext{
${ }^{24}$ We also conduct a more formal test of independence between the mortgage prepayment and TDA contribution decisions, which is discussed later in this section.
} 
a necessary condition for writing off mortgage interest expense) has a strong negative effect, with itemizers being 8 percentage points less likely to hold a short mortgage.

Taking out a short mortgage requires a commitment to higher monthly cash payments. Consequently, we find strong effects for variables that indicate availability of financial resources. In particular, liquidity-constrained households are found to be 9 percentage points less likely to have a short mortgage. Household net worth is another key factor behind this decision. The estimated coefficient suggests that each percentage point increase in net worth leads to about a $5 \%$ rise in the probability of prepayment via a short mortgage. In a similar vein, we find that households making PMI payments are less likely to take out short-term mortgages. On the other hand, there is no evidence that residing in a high-exemption state affects the term of the mortgage significantly.

We further find that more risk-averse households are marginally more likely to hold short mortgages. One of the frequently told stories for mortgage prepayment is the desire to be "free of debt," even if it entails sacrificing current consumption to achieve this goal. Thus, we would expect households that strive to be debt-free to make natural candidates for committed prepayment in the form of a short mortgage. Consistent with this conjecture, we find that debt averse households are more likely to choose short mortgages (and, as shown later, make discretionary prepayments). ${ }^{25}$

In sum, the decision to have a short maturity mortgage is affected by a number of variables that conform to rational models of financial decision-making. There is some evidence that households making such choice have less to gain from the interest rate deduction, have the financial wherewithal for higher payments (higher net worth and no liquidity constraints), and are more debt-averse.

\footnotetext{
${ }^{25}$ One could make a case for the endogeneity of our measure of debt aversion, since the decision to pay off a credit card and make an extra mortgage payment are made simultaneously. However, as argued earlier, paying off credit card balances in full is an indicator of household consumption and savings tastes. As such, this variable provides useful information of what otherwise would be an omitted measure of household heterogeneity, and it is kept in reported regression specifications. For robustness, we re-estimated all regressions without this variable. Omitting debt aversion makes the effect of net worth more positive and raises its statistical significance. There are no qualitative changes in any of the other coefficients.
} 
It is more difficult to find influence of such rational factors on the decision to make discretionary prepayments, however. As shown in the middle column of Table 7 , few factors have statistically significant explanatory power for the household choice to write additional checks to their mortgage company. We still find that being subject to liquidity constraints serves as a barrier to making mortgage prepayments, even when such prepayments do not require the commitment associated with short maturity mortgages. Also, debt aversion increases the likelihood of discretionary prepayments. However, there is no evidence that a household's financial position (whether in the form of net worth or current income as proxied by the tax variables) plays a role in this decision. Nor is there much support for the motive to eliminate PMI or build up more home equity for possible bankruptcy. Moreover, the estimated coefficient on the borrowing-lending spread is negative, implying that households for whom the current investment opportunities are poor (high spread) are nevertheless less likely to pay off their expensive mortgage obligations.

For completeness, we model the TDA contribution decision as a function of the same set of factors. The estimation results are shown in the rightmost column of Table 7 . We find that households with high current income (i.e. those in high tax brackets) and those itemizing tax deductions are more likely to contribute. Once again, we find evidence of the importance of liquidity constraints, as liquidity constrained households shy away from making TDA contributions. There is also a strong negative cohort effect in TDA participation.

Interestingly, more risk averse households are less likely to contribute to TDAs, although risk aversion affects the prepayment decision only marginally. Debt aversion, on the other hand, fails to show up in TDA contributions even though it features prominently in prepayment decisions. The TDA contribution decision is also strongly positively affected by the size of the employer match, which plays no role in the prepayment 
decision. These results raise the possibility that the two types of decisions are somewhat separable.

A better way to assess this hypothesis is to evaluate the likelihood of prepayment and TDA contributions jointly, by allowing the error terms of these decisions to be correlated. There may well be some unobserved factors that influence each of these decisions, biasing the single-equation coefficients. To account for this possibility, we estimate an unreported bivariate probit model of contribution and prepayment decisions. Each equation contains one unique regressor to help with identification. The size of the TDA match is excluded from the prepayment equation, while a dummy variable identifying PMI-paying households is excluded from the contribution equation. Each of the excluded variables is conjectured to influence one of the decisions without having a direct effect on the other.

We cannot reject the hypothesis of independence between the two savings decisions regardless of the way mortgage repayment is defined. To check whether some households follow the explicit tradeoff implied by the MAP measure and whether their preference and knowledge affect this decision, we turn to the analysis of the composition of savings in the next section.

\subsection{Relative Preference for Contributions vs. Prepayments}

The dependent variable in this subsection, TDAFraction, captures the fraction of relevant savings that is directed towards tax-deferred contributions rather than prepayments.

$$
\text { TDAFraction } \equiv \frac{\text { TDAContribution }}{\text { Prepayment }+ \text { TDAContribution }},
$$

where Prepayment is defined in turn as (i) the imputed prepayment from holding a short mortgage, and (ii) the discretionary prepayment, and TDAContribution is the total dollar contribution of all household members. TDAFraction is continuous by 
construction, with values ranging from 0 to 1.

We proceed to estimate a variant of equation (4) using TDAFraction as the dependent variable and modifying the vector of explanatory variables in two ways. First, we replace $M A P$ components with the $M A P$ itself. Since we are now looking explicitly at the relative taste for TDA contributions versus prepayments, $M A P$ is the proper measure for capturing the influence of "rational" factors, in spite of its inherent nonlinearity. In other words, if households are aware of the tax-arbitrage strategy, the $M A P$ measure should explain part of the cross-sectional differences in TDAFraction.

Recall that in theory higher $M A P$ values indicate larger tax benefits for substituting mortgage prepayments for TDA contributions. It is possible that the degree to which households relate MAP to this tradeoff varies with certain household characteristics. For instance, debt-averse households may be pre-occupied by the motive to reduce mortgage debt and thus pay less attention to MAP, leading to a weaker positive relationship with TDAFraction. To test this, we add interactions of $M A P$ with preference and information variables to the vector of regressors.

Note that TDAFraction cannot be defined for households that make no TDA contributions and no mortgage prepayments (henceforth, 0-0 households). The resulting sample truncation opens up the possibility of selection bias. Therefore, prior to estimating a Tobit version of (4) for TDAFraction, we test for sample selection using a standard Heckman two-step estimator (Heckman, 1976). We use self-reported saving habits as instruments for identifying the choice to make at least one of the two savings decisions and thus to be excluded from the 0-0 group. We find that households that save regularly are indeed more likely to make prepayments or TDA contributions. However, the estimated inverse Mills ratio is not statistically different from zero, and we therefore proceed to estimate regressions for TDAFraction on the truncated sample without making adjustments for sample selection bias. 
Table 8 presents the results for both definitions of prepayments. The comparison of estimated MAP coefficients across the two prepayment types is quite jarring. Recall that the intuition for $M A P$ was derived from a hypothetical conversion of a dollar in discretionary prepayments to a dollar in TDA contributions. Yet, although the tradeoff between discretionary prepayments and TDA contributions is ideally suited to be made on the basis of $M A P$, the estimated coefficient is of the wrong sign. It is surprising that, on average, households for whom it is more advantageous to channel discretionary prepayments into TDA contributions do precisely the opposite. In contrast, the revealed taste for contributions is substantially higher for short-mortgage households with high $M A P$ values.

Specifications in columns (2) and (4) further decompose the effects of $M A P$ on this tradeoff. In the case of short mortgage prepayments, having access to better financial information (either through a financial advisor or through a better education) substantially increases the likelihood of making the right choice, as both $M A P$ interaction terms on these variables are strongly positive. However, we fail to detect any moderating effect of better information on making the correct choice in the case of discretionary prepayments. For both types of prepayments we find little evidence that household preferences influence the mortgage-TDA tradeoff through $M A P$. There is also no measurable difference for households not subject to TDA withdrawal penalties, for whom TDA savings have few drawbacks. In the case of discretionary prepayments, this means that nonpenalized households are just as likely to be forgoing the arbitrage, reminiscent of the results in Choi, Laibson, and Madrian (2005).

Similar to the results in Table 7, we find that characteristics other than $M A P$ influence households' relative preferences towards mortgage prepayment or TDA savings. As argued earlier in section 3.3, it is difficult to claim that home equity is unambiguously more liquid that TDA assets. The results in Table 8 are consistent with this view. In 
only one of the specifications the liquidity-constrained households are found to have different relative preferences. Even in this case, they display a greater taste for retirement contributions, contrary to the common view that home equity provides better liquidity. Notwithstanding the relative strength of the effects of liquidity constraints on prepayments and TDA contributions (see Table 7), both of these forms of savings appear to be negatively affected by liquidity considerations. This suggests that liquidity-constrained households may prefer to first build up wealth in liquid taxable accounts instead.

Preference heterogeneity shows up consistently in each of the specifications. We find that households that are more risk- and debt-averse generally favor mortgage prepayments over TDA contributions. The finding that debt-averse households focus on paying off their debt obligations is consistent with the hypothesis that preferences for specific forms of wealth may override the goal of maximizing the overall wealth level.

\section{Conclusion}

We characterize the optimal tradeoff between contributing an extra dollar of savings towards accelerating mortgage payments and saving that extra dollar in tax-qualified retirement accounts. We show that it is often a tax-arbitrage to reduce prepayments and increase TDA contributions. We document actual household behavior using data from the Survey of Consumer Finances, and conclude that about $38 \%$ of households who prepay their mortgages could benefit from our proposed arbitrage strategy. Depending on the choice of the investment asset in the TDA, the median gain from such a reallocation ranges between 11 and 17 cents per dollar of "mis-allocated savings". Finally, we show empirically that this inefficient behavior is unlikely to be driven by liquidity or other constraints, and that self-reported debt aversion and risk aversion variables explain to some extent the household preference for paying off their debt obligations early and hence the propensity to forgo our tax arbitrage. 


\section{References}

[1] Agnew, Julie, Pierluigi Balduzzi, and Annika Sunden, 2003, Portfolio Choice and Trading in a Large 401(k) Plan, American Economic Review, 93 (1), 193-215.

[2] Amromin, Gene, 2004, Portfolio Allocation Choices in Taxable and Tax-Deferred Accounts: An Empirical Analysis of Tax Efficiency, Board of Governors of the Federal Reserve System Working Paper.

[3] Barber, Brad, and Terrance Odean, 2003, Are Individual Investors Tax Savvy? Evidence from Retail and Discount Brokerage Accounts, Journal of Public Economics, $88,419-442$.

[4] Bergstresser, Daniel, and James M. Poterba, 2004, Asset Allocation and Asset Location: Household Evidence from the Survey of Consumer Finances, Journal of Public Economics, 88, 1893-1915.

[5] Benartzi, Shlomo, and Richard H. Thaler, 2001, Naive Diversification Strategies in Defined Contribution Saving Plans, American Economic Review, 91 (1), 79-98.

[6] Bodie, Zvi, and Dwight B. Crane, 1997, Personal Investing: Advice, Theory, and Evidence, Financial Analysts Journal, 13-23.

[7] Brown, Jeffrey R., Nellie Liang, and Scott Weisbenner, 2006, Individual Account Investment Options and Portfolio Choice: Behavioral Lessons from 401(k) Plans, University of Illinois at Urbana-Champaign Working Paper.

[8] Campbell, John Y., 2006, Household Finance, Forthcoming: Journal of Finance.

[9] Campbell, John Y. and Joao F. Cocco, 2003, Household Risk Management and Optimal Mortgage Choice, Quarterly Journal of Economics, 118 (4), 1449-1494. 
[10] Choi, James J., David Laibson, and Brigitte C. Madrian, 2004, Plan Design and 401(k) Savings Outcomes, National Tax Journal, 57 (2), 275-298.

[11] Choi, James J., David Laibson, and Brigitte C. Madrian, 2005, \$100 Bills on the Sidewalk: Suboptimal Saving in 401(k) Plans, Yale University Working Paper.

[12] Choi, James J., David Laibson, Brigitte C. Madrian, and Andrew Metrick, 2004, For Better or for Worse: Default Effects and 401(k) Savings Behavior, In Perspectives on the Economics of Aging, edited by David A. Wise. Chicago: Univ. Chicago Press (for NBER).

[13] Choi, James J. David Laibson, Brigitte C. Madrian, and Andrew Metrick, 2002, Defined Contribution Pensions: Plan Rules, Participation Choices, and the Path of Least Resistence, Tax Policy and the Economy, 16, 67-113.

[14] Cunningham, Christopher R. and Gary V. Engelhardt, 2002, Federal Tax Policy, Employer Matching, and 401(k) Saving: Evidence from HRS W-2 Records, National Tax Journal, 55 (3), 617-645.

[15] Dammon, Robert M., Chester S. Spatt, and Harold H. Zhang, 2004, Optimal Asset Location and Allocation with Taxable and Tax-Deferred Investing, Journal of Finance, 59, 999-1037.

[16] Duflo, Esther, William Gale, Jeffrey Liebman, Peter Orszag, and Emmanuel Saez, 2006, Saving Incentives for Low- and Middle-Income Families: Evidence from a Field Experiment with H\&R Block, Forthcoming: Quarterly Journal of Economics.

[17] Duflo, Esther and Emmanuel Saez, 2003, The Role of Information and Social Interactions in Retirement Plan Decisions: Evidence from a Randomized Experiment, Quarterly Journal of Economics, 118 (3), 815-842. 
[18] Engelhardt, Gary V. and Anil Kumar, 2006, Employer Matching and 401(k) Saving: Evidence from the Health and Retirement Study, Syracuse University Working Paper.

[19] Fay, Scott, Erik Hurst, and Michelle J. White, 2002, The Household Bankruptcy Decision, American Economic Review, 92 (3), 706-718.

[20] Feenberg, Daniel R. and Elisabeth Coutts, 1993, An introduction to the TAXSIM model, Journal of Policy Analysis and Management, 12 (1), 189-194.

[21] Fu, Qiang, Michael Lacour-Little, and Kerry Vandell, 1997, Retiring Early: an Empirical Analysis of the Mortgage Curtailment Decision, University of Wisconsin Center for Urban Land Economic Research Working Paper 97-09.

[22] Garlappi, Lorenzo, and Jennifer Huang, 2006, Are Stocks Desirable in Tax-Deferred Accounts? Journal of Public Economics, forthcoming.

[23] Graham, John R., 2000, How Big Are the Tax Benefits of Debt? Journal of Finance, 55 (5), 1901-1942.

[24] Gross, David B. and Nicholas S. Souleles, 2002, Do Liquidity Constraints and Interest Rates Matter for Consumer Behavior? Evidence from Credit Card Data Quarterly Journal of Economics, 117 (1), 149-185.

[25] Heckman, James J., 1976, The Common Structure of Statistical Models of Truncation, Sample Selection, and Limited Dependent Variables and A Simple Estimator for Such Models, Annals of Economic and Social Measurement, 5, 475-492.

[26] Haliassos, Michael and Michael Reiter, 2005, Credit Card Debt Puzzles, University of Frankfurt Working Paper 2005/26. 
[27] Hoynes, Hilary W. and Daniel McFadden, 1997, The Impact of Demographics on Housing and Nonhousing Wealth in the United States, In M. Hurd and N. Yashiro (Eds.), The Economic Effects of Aging in the United States and Japan, University of Chicago Press: Chicago, 153-194.

[28] Huang, Jennifer, 2005, Portfolio Decisions with Taxable and Tax-Deferred Accounts: A Tax-Arbitrage Approach, University of Texas at Austin Working Paper.

[29] Huberman, Gur and Wei Jiang, 2006, Offering vs. Choice in 401(k) Plans: Equity Exposure and Number of Funds, Journal of Finance, 61 (2), 763-801.

[30] Hurst, Erik and Frank Stafford, 2004, Home Is Where the Equity Is: Mortgage Refinancing and Household, Journal of Money, Credit, and Banking, 36 (6), 9851014 .

[31] Kennickell, Arthur B. and Martha Starr-McCluer, 1994, Changes in Family Finances from 1989 to 1992: Evidence from the Survey of Consumer Finances, Federal Reserve Bulletin, 80, 861-882.

[32] Madrian, Brigitte C. and Dennis F. Shea, 2001, The Power of Suggestion: Inertia in 401(k) Participation and Savings Behavior, Quarterly Journal of Economics, 116 (4), 1149-1187.

[33] Mitchell, Olivia S., Stephen P. Utkus, and Tongxuan (Stella) Yang, 2005, Better Plans for the Better-Paid: Determinants and Effects of 401(k) Plan Design, University of Pennsylvania Working Paper.

[34] Pence, Karen M., 2001, 401(k)s and Household Saving: New Evidence from the Survey of Consumer Finances, Board of Governors of the Federal Reserve System Working Paper. 
[35] Poterba, James M., 2000, Stock Market Wealth and Consumption, Journal of Economic Perspectives, 14 (2), 99-118.

[36] Poterba, James M., John B. Shoven, and Clemens Sialm, 2004, Asset Location for Retirement Savers, In William G. Gale et al. (Editors). Private Pensions and Public Policies, Washington: Brookings Institution, 290-331.

[37] Poterba, James M., Steven F. Venti, and David A. Wise, 1995, Do 401(K) Contributions Crowd Out Other Personal Saving? Journal of Public Economics, 58, $1-32$.

[38] Quigley, John M., 2002, Homeowner Mobility and Mortgage Interest Rates: New Evidence from the 1990s, Real Estate Economics, 30 (3), 345-364.

[39] Shoven, John B., and Clemens Sialm, 2004, Asset Location in Tax-Deferred and Conventional Savings Accounts, Journal of Public Economics, 88, 23-38.

[40] Sialm, Clemens, 2006, Investment Taxes and Equity Returns, NBER Working Paper No. 12146 .

[41] Vissing-Jorgensen, 2002, Limited Asset Market Participation and the Elasticity of Intertemporal Substitution, Journal of Political Economy, 110, 825-853.

[42] White, Michelle J., 1998, Why Don’t More Households File for Bankruptcy? Journal of Law, Economics, and Organization, 14 (2), 205-231. 


\section{Table 1: Characteristics of All Households}

This table summarizes some characteristics of households from the 1995, 1998, and 2001 Surveys of Consumer Finances. The first column summarizes the characteristics of all households, the second column summarizes the characteristics of households that are eligible to contribute to an employer-sponsored retirement account, and the third column summarizes the characteristics of households that are eligible to contribute to an employer-sponsored retirement account and that currently have a fixed-rate mortgage outstanding. The number in the first row of each characteristic corresponds to the weighted mean, where the weights are the population weights provided by the Survey of Consumer Finances. The two numbers in brackets correspond to the interquartile ranges of the characteristics.

\begin{tabular}{|c|c|c|c|}
\hline Variable & $\begin{array}{c}\text { All } \\
\text { Households }\end{array}$ & $\begin{array}{l}\text { All Eligible } \\
\text { Households }\end{array}$ & $\begin{array}{c}\text { All Eligible } \\
\text { Households } \\
\text { with Fixed } \\
\text { Mortgage }\end{array}$ \\
\hline Number of Observations & 13,046 & 8,569 & 2,684 \\
\hline Number of Households & $102.7 \mathrm{M}$ & $46.6 \mathrm{M}$ & $22.8 \mathrm{M}$ \\
\hline Age & $\begin{array}{c}48.7 \\
{[35-61]}\end{array}$ & $\begin{array}{c}42.5 \\
{[34-50]}\end{array}$ & $\begin{array}{c}43.6 \\
{[37-50]}\end{array}$ \\
\hline Proportion Married (in \%) & 59.2 & 71.9 & 82.4 \\
\hline Proportion with College (in \%) & 32.8 & 43.4 & 49.0 \\
\hline Proportion with High School (in \%) & 83.2 & 93.0 & 95.1 \\
\hline Risk-Aversion Score & $\begin{array}{c}3.2 \\
{[3-4]}\end{array}$ & $\begin{array}{c}2.9 \\
{[2-4]}\end{array}$ & $\begin{array}{c}2.8 \\
{[2-3]}\end{array}$ \\
\hline Proportion that are Debt Averse (in \%) & 39.2 & 40.6 & 37.9 \\
\hline Proportion with Liquidity Constraints & 28.9 & 29.7 & 22.4 \\
\hline Normal Income & $\begin{array}{c}54,211 \\
{[19,267-61,675]}\end{array}$ & $\begin{array}{c}71,887 \\
{[34,949-79,149]}\end{array}$ & $\begin{array}{c}85,174 \\
{[45,069-92,512]}\end{array}$ \\
\hline Federal Tax Bracket & $\begin{array}{c}16.5 \\
{[15-28]}\end{array}$ & $\begin{array}{c}22.2 \\
{[15-28]}\end{array}$ & $\begin{array}{c}24.1 \\
{[15-28]}\end{array}$ \\
\hline Liquid Financial Wealth & $\begin{array}{c}85,276 \\
{[870-36,720]}\end{array}$ & $\begin{array}{c}78,061 \\
{[2,100-40,800]}\end{array}$ & $\begin{array}{c}81,399 \\
{[4,200-58,000]}\end{array}$ \\
\hline Retirement Wealth & $\begin{array}{c}36,216 \\
{[0-18,100]}\end{array}$ & $\begin{array}{c}54,075 \\
{[80-43,000]}\end{array}$ & $\begin{array}{c}66,673 \\
{[2,200-65,000]}\end{array}$ \\
\hline Credit Card Balance & $\begin{array}{c}1,699 \\
{[0-1,300]}\end{array}$ & $\begin{array}{c}2,362 \\
{[0-2,650]}\end{array}$ & $\begin{array}{c}2,572 \\
{[0-3,100]}\end{array}$ \\
\hline Net Worth & $\begin{array}{c}280,689 \\
{[9,700-205,600]}\end{array}$ & $\begin{array}{c}285,841 \\
{[24,600-222,980]}\end{array}$ & $\begin{array}{c}314,458 \\
{[58,080-287,800]}\end{array}$ \\
\hline
\end{tabular}


Table 2: Characteristics of Households According to Prepayment and Contribution Behavior

This table summarizes some characteristics of households from the 1995, 1998, and 2001 Surveys of Consumer Finances according to their prepayment and contribution behavior. The sample consists of households that have fixed-rate mortgages and are eligible for employer-sponsored TDAs. The number in the first row of each characteristic corresponds to the weighted mean, where the weights are the population weights provided by the Survey of Consumer Finances. The two numbers in brackets correspond to the interquartile ranges of the characteristics.

\begin{tabular}{|c|c|c|c|c|}
\hline \multirow{2}{*}{ 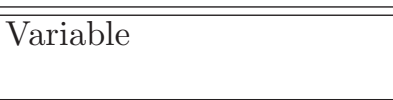 } & \multicolumn{2}{|c|}{ No Contributions } & \multicolumn{2}{|c|}{ Contributions } \\
\hline & No Prepay & Prepay & No Prepay & Prepay \\
\hline \multicolumn{5}{|c|}{ Panel A: Prepayment and Contribution Behavior } \\
\hline $\begin{array}{l}\text { Number of Observations } \\
\text { Number of Households } \\
\text { Contribution } \\
\text { Contribution Gap } \\
\text { Total Prepayments } \\
\text { Discretionary } \\
\text { Prepayments } \\
\text { Short Mortgage } \\
\text { Prepayments }\end{array}$ & $\begin{array}{c}5,257 \\
{[3,000-6,700]}\end{array}$ & $\begin{array}{c}6,149 \\
{[3,400-8,600]} \\
2,712 \\
{[728-2,782]} \\
953 \\
{[0-826]} \\
1,759 \\
{[0-1,947]} \\
\end{array}$ & $\begin{array}{c}867 \\
7.8 \mathrm{M} \\
4,966 \\
{[1,680-6,400]} \\
2,770 \\
{[180-4,200]}\end{array}$ & $\begin{array}{c}908 \\
7.1 \mathrm{M} \\
5,506 \\
{[1,800-7,400]} \\
2,864 \\
{[200-4,260]} \\
3,345 \\
{[858-3,386]} \\
1,735 \\
{[0-1,271]} \\
1,610 \\
{[0-2,107]}\end{array}$ \\
\hline \multicolumn{5}{|l|}{ Panel B: Wealth Levels } \\
\hline $\begin{array}{l}\text { Liquid Financial Wealth } \\
\text { Retirement Wealth } \\
\text { Home Equity } \\
\text { Net Worth }\end{array}$ & $\begin{array}{c}60,775 \\
{[2,101-32,500]} \\
22,943 \\
{[0-11,000]} \\
61,593 \\
{[16,000-77,000]} \\
210,508 \\
{[35,300-163,800]}\end{array}$ & $\begin{array}{c}90,051 \\
{[5,000-72,650]} \\
56,101 \\
{[0-36,000]} \\
93,190 \\
{[28,000-113,000]} \\
363,152 \\
{[65,200-367,600]}\end{array}$ & $\begin{array}{c}67,515 \\
{[3,600-42,000]} \\
71,344 \\
{[7,000-73,000]} \\
63,464 \\
{[17,000-75,000]} \\
265,282 \\
{[51,200-258,400]} \\
\end{array}$ & $\begin{array}{c}105,348 \\
{[8,000-87,700]} \\
94,393 \\
{[12,500-105,000]} \\
90,580 \\
{[31,000-111,000]} \\
411,311 \\
{[91,350-387,240]}\end{array}$ \\
\hline \multicolumn{5}{|c|}{ Panel C: Mortgage Characteristics (in \%) } \\
\hline $\begin{array}{l}\text { Mortgage Rate } \\
\text { Loan/Value Ratio } \\
\text { Federal Tax Bracket }\end{array}$ & $\begin{array}{c}8.00 \\
{[7.00-8.50]} \\
58.5 \\
{[35.6-80.0]} \\
21.7 \\
{[15-28]}\end{array}$ & $\begin{array}{c}7.81 \\
{[7.00-8.30]} \\
45.9 \\
{[25.7-64.1]} \\
23.8 \\
{[15-28]}\end{array}$ & $\begin{array}{c}7.87 \\
{[7.00-8.50]} \\
61.8 \\
{[45.4-80.0]} \\
24.2 \\
{[15-28]}\end{array}$ & $\begin{array}{c}7.59 \\
{[6.95-8.00]} \\
50.1 \\
{[32.3-68.4]} \\
25.7 \\
{[15-28]}\end{array}$ \\
\hline \multicolumn{5}{|c|}{ Panel D: Households with Credit Card Debt } \\
\hline $\begin{array}{l}\text { Proportion with Debt } \\
\text { Median Balance } \\
\text { Median Interest Rate } \\
\text { Median Liquid Assets }\end{array}$ & $\begin{array}{c}53.0 \\
2,400 \\
14.3 \\
3,000\end{array}$ & $\begin{array}{c}44.7 \\
2,000 \\
12.0 \\
3,700\end{array}$ & $\begin{array}{c}52.8 \\
3,000 \\
14.0 \\
3,200\end{array}$ & $\begin{array}{c}43.9 \\
3,000 \\
12.5 \\
4,500\end{array}$ \\
\hline
\end{tabular}




\section{Table 3: Forgone Arbitrage Opportunities}

This table summarizes the marginal (MAP) and the total arbitrage profits (TAP) for households which have positive MAPs based on the 1995, 1998, and 2001 Surveys of Consumer Finances. The number in the first row of each characteristic corresponds to the weighted mean, where the weights are the population weights provided by the Survey of Consumer Finances. The two numbers in brackets correspond to the interquartile ranges of the characteristics. Panels A and B correspond to the MAP and TAP computed using the investment rates from Mortgage-Backed Securities and from Treasury Bonds, respectively.

\begin{tabular}{|c|c|c|c|c|}
\hline & \multicolumn{2}{|c|}{ No Contributions } & \multicolumn{2}{|c|}{ Contributions } \\
\hline & No Prepay & Prepay & No Prepay & Prepay \\
\hline \multicolumn{5}{|l|}{ Panel A: Using MBS Rate for TDA investments } \\
\hline Number of Households with MAP $>0$ & $2.2 \mathrm{M}$ & $1.5 \mathrm{M}$ & $4.5 \mathrm{M}$ & $3.5 \mathrm{M}$ \\
\hline Proportion of Households with MAP $>0$ (in \%) & 48.9 & 43.4 & 58.2 & 48.8 \\
\hline \multirow[t]{2}{*}{ MAP (in \%) } & 21.4 & 17.2 & 22.9 & 16.6 \\
\hline & {$[10.0-31.2]$} & {$[7.7-23.7]$} & {$[11.9-33.7]$} & {$[7.9-24.8]$} \\
\hline Number of Households with TAP $>0$ & 0 & $1.5 \mathrm{M}$ & 0 & $2.5 \mathrm{M}$ \\
\hline \multirow[t]{2}{*}{ TAP from All Prepayments } & & 394 & & 375 \\
\hline & & {$[77-403]$} & & {$[54-471]$} \\
\hline TAP from Discretionary Prepayments & & $\begin{array}{c}265 \\
{[0-223]}\end{array}$ & & $\begin{array}{c}280 \\
{[0-326]}\end{array}$ \\
\hline \multirow[t]{2}{*}{ TAP from Short Mortgage } & & 151 & & 107 \\
\hline & & {$[0-156]$} & & {$[0-137]$} \\
\hline \multicolumn{5}{|l|}{ Aggregate TAP $=\$ 1.528$ Billion } \\
\hline \multicolumn{5}{|l|}{ Panel B: Using T-Bond Rate for TDA investments } \\
\hline Number of Households with MAP $>0$ & $1.1 \mathrm{M}$ & $0.9 \mathrm{M}$ & $2.7 \mathrm{M}$ & $2.1 \mathrm{M}$ \\
\hline Proportion of Households with MAP $>0$ (in \%) & 26.3 & 28.6 & 35.1 & 30.0 \\
\hline \multirow[t]{2}{*}{ MAP (in \%) } & 16.0 & 10.9 & 14.6 & 10.4 \\
\hline & {$[6.9-25.0]$} & {$[2.3-14.8]$} & {$[6.2-20.9]$} & {$[4.4-14.9]$} \\
\hline Number of Households with TAP $>0$ & 0 & $0.9 \mathrm{M}$ & 0 & $1.6 \mathrm{M}$ \\
\hline TAP from All Prepayments & & $\begin{array}{c}281 \\
{[28-338]}\end{array}$ & & $\begin{array}{c}240 \\
{[41-289]}\end{array}$ \\
\hline \multirow[t]{2}{*}{ TAP from Discretionary Prepayments } & & 188 & & 164 \\
\hline & & {$[0-93]$} & & {$[0-210]$} \\
\hline \multirow{2}{*}{ TAP from Short Mortgage } & & 112 & & 82 \\
\hline & & {$[0-116]$} & & {$[0-83]$} \\
\hline
\end{tabular}




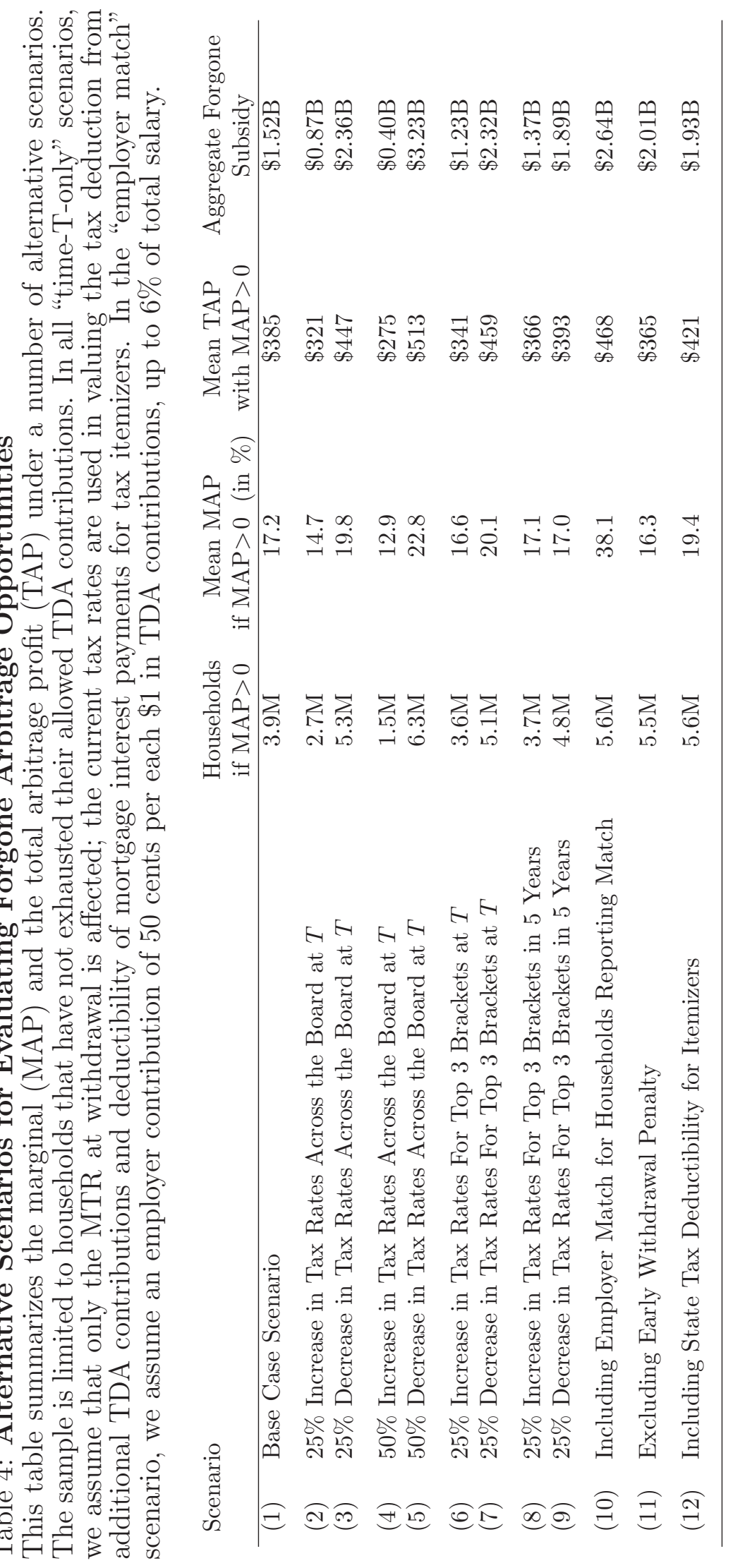




\section{Table 5: Characteristics of Households Which Prepay Mortgage}

This table summarizes the characteristics of households from the 1995, 1998, and 2001 Surveys of Consumer Finances depending on whether they have positive or negative MAPs. Prepayments include both discretionary prepayments and prepayments due to a short-term mortgage. The number in the first row of each characteristic corresponds to the weighted mean, where the weights are the population weights provided by the Survey of Consumer Finances. The two numbers in brackets correspond to the interquartile ranges of the characteristics.

\begin{tabular}{lcccc}
\hline \hline Variable & \multicolumn{2}{c}{ No Contributions } & \multicolumn{2}{c}{ Partial Contributions } \\
& Gain & Loss & Gain & Loss \\
\hline Panel A: Main Determinants of Total Benefits & & & \\
Number of Households & $1.5 \mathrm{M}$ & $1.9 \mathrm{M}$ & $2.5 \mathrm{M}$ & $3.0 \mathrm{M}$ \\
Age & 48.3 & 44.5 & 44.6 & 41.0 \\
& {$[41-54]$} & {$[37-52]$} & {$[38-51]$} & {$[34-48]$} \\
Mortgage Rate (in \%) & 7.22 & 8.26 & 7.20 & 7.97 \\
Mortgage Spread (in \%) & {$[6.75-7.50]$} & {$[7.25-9.00]$} & {$[6.75-7.58]$} & {$[7.00-8.50]$} \\
& -0.19 & 0.84 & -0.10 & 0.52 \\
Federal Tax Bracket (in \%) & {$[-0.80-0.43]$} & {$[-0.20-1.45]$} & {$[-0.64-0.49]$} & {$[-0.25-1.01]$} \\
& 27.3 & 21.1 & 27.3 & 23.1 \\
\hline Panel B: Financial Characteristics & {$[28-31]$} & {$[15-28]$} & {$[28-28]$} & {$[15-28]$} \\
Liquid Financial Wealth & 142,063 & 51,609 & & \\
& {$[13,000-144,700]$} & {$[2,970-41,500]$} & {$[11,420-78,000]$} & {$[4,750-56,400]$} \\
Retirement Wealth & 93,869 & 27,151 & 87,401 & 58,091 \\
& {$[0-98,000]$} & {$[0-15,000]$} & {$[12,650-102,000]$} & {$[6,500-64,000]$} \\
Home Equity & 125,490 & 68,463 & 93,058 & 72,056 \\
& {$[42,000-151,000]$} & {$[25,000-79,000]$} & {$[34,000-113,000]$} & {$[23,000-100,000]$} \\
Loan to Value Ratio (in \%) & 48.9 & 43.5 & 53.6 & 48.8 \\
& {$[30.5-66.1]$} & {$[22.3-63.3]$} & {$[37.9-71.7]$} & {$[30.0-70.5]$} \\
Net Worth & 551,529 & 220,216 & 371,231 & 250,537 \\
& {$[117,480-510,850]$} & {$[46,410-203,820]$} & {$[97,200-381,790]$} & {$[60,800-275,000]$} \\
\hline \hline
\end{tabular}




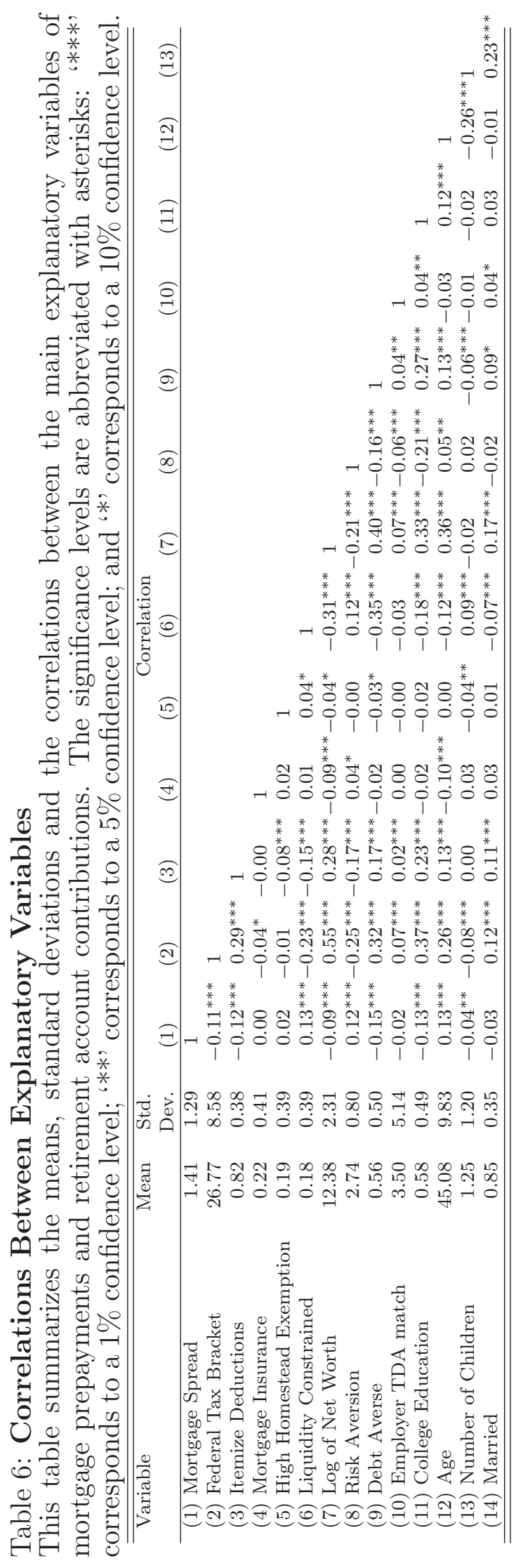


Table 7: Determinants of Prepayment and Contribution Behavior

This table summarizes the determinants of the prepayment and contribution behavior for households from the 1995, 1998, and 2001 Surveys of Consumer Finances. The dependent variables are indicator variables of (1) whether households have a short mortgage, (2) whether they make discretionary prepayments, and (3) whether they contribute to a TDA. The table summarizes the marginal effects of the probit regressions. The regressions also include unreported mortgage origination year fixed effects. The changes in the probabilities are expressed in percent. The robust standard errors are summarized in parentheses. The significance levels are abbreviated with asterisks: '***', '**', and '*' correspond to a $1 \%, 5 \%$, and $10 \%$ confidence levels, respectively.

\begin{tabular}{|c|c|c|c|}
\hline Variable & $\begin{array}{c}\text { Short } \\
\text { Mortgage } \\
\end{array}$ & $\begin{array}{l}\text { Discretionary } \\
\text { Prepayments } \\
\end{array}$ & $\begin{array}{c}\text { Retirement } \\
\text { Contributions }\end{array}$ \\
\hline Mortgage Spread (in ppt) & $\begin{array}{l}8.78^{* * *} \\
(1.02)\end{array}$ & $\begin{array}{c}-1.59^{* *} \\
(0.73)\end{array}$ & $\begin{array}{c}-0.76 \\
(0.80)\end{array}$ \\
\hline Federal Tax Bracket (in ppt) & $\begin{array}{l}0.08 \\
(0.16)\end{array}$ & $\begin{array}{c}0.03 \\
(0.13)\end{array}$ & $\begin{array}{l}0.34^{* *} \\
(0.14)\end{array}$ \\
\hline Itemize Deductions & $\begin{array}{c}-8.29^{* * *} \\
(2.93)\end{array}$ & $\begin{array}{c}1.03 \\
(2.26)\end{array}$ & $\begin{array}{l}6.55^{* *} \\
(2.72)\end{array}$ \\
\hline Mortgage Insurance & $\begin{array}{c}-8.19^{* * *} \\
(2.39)\end{array}$ & $\begin{array}{r}-1.76 \\
(1.89)\end{array}$ & $\begin{array}{l}1.19 \\
(2.24)\end{array}$ \\
\hline High Homestead Exemption & $\begin{array}{c}0.01 \\
(2.57)\end{array}$ & $\begin{array}{l}1.52 \\
(2.05)\end{array}$ & $\begin{array}{l}3.05 \\
(2.33)\end{array}$ \\
\hline Liquidity Constrained & $\begin{array}{c}-9.11^{* * *} \\
(2.80)\end{array}$ & $\begin{array}{c}-6.16^{* * *} \\
(2.14)\end{array}$ & $\begin{array}{c}-5.32^{* *} \\
(2.71)\end{array}$ \\
\hline Log of Net Worth & $\begin{array}{l}4.72^{* * *} \\
(0.91)\end{array}$ & $\begin{array}{c}0.19 \\
(0.65)\end{array}$ & $\begin{array}{c}0.05 \\
(0.82)\end{array}$ \\
\hline Risk Aversion & $\begin{array}{c}2.39^{*} \\
(1.35)\end{array}$ & $\begin{array}{l}-1.60 \\
(1.06)\end{array}$ & $\begin{array}{l}-5.40^{* * *} \\
(1.28)\end{array}$ \\
\hline Debt Averse & $\begin{array}{l}6.06^{* * *} \\
(2.31)\end{array}$ & $\begin{array}{l}8.82^{* * *} \\
(1.79)\end{array}$ & $\begin{array}{c}0.10 \\
(2.19)\end{array}$ \\
\hline College Education & $\begin{array}{c}-3.71 \\
(2.29)\end{array}$ & $\begin{array}{c}-0.71 \\
(1.82)\end{array}$ & $\begin{array}{l}1.13 \\
(2.11)\end{array}$ \\
\hline Use Professional Advice & $\begin{array}{c}-0.78 \\
(2.04)\end{array}$ & $\begin{array}{l}1.85 \\
(1.62)\end{array}$ & $\begin{array}{c}-2.27 \\
(1.95)\end{array}$ \\
\hline Employer TDA match (in ppt) & $\begin{array}{c}0.13 \\
(0.20)\end{array}$ & $\begin{array}{c}-0.08 \\
(0.16)\end{array}$ & $\begin{array}{l}2.20^{* * * *} \\
(0.39)\end{array}$ \\
\hline Age (in yrs) & $\begin{array}{l}0.83^{* * *} \\
(0.15)\end{array}$ & $\begin{array}{c}-0.23^{* *} \\
(0.11)\end{array}$ & $\begin{array}{c}-0.44^{* * *} \\
(0.14)\end{array}$ \\
\hline Not Subject to TDA Penalty & $\begin{array}{c}-9.04^{* *} \\
(4.36)\end{array}$ & $\begin{array}{c}2.62 \\
(3.92)\end{array}$ & $\begin{array}{r}-8.70^{*} \\
(4.60)\end{array}$ \\
\hline Number of Children & $\begin{array}{l}1.57^{*} \\
(0.90)\end{array}$ & $\begin{array}{c}-1.71^{* *} \\
(0.70)\end{array}$ & $\begin{array}{c}-1.30 \\
(0.85)\end{array}$ \\
\hline Married & $\begin{array}{c}2.90 \\
(2.98)\end{array}$ & $\begin{array}{l}-0.40 \\
(2.41)\end{array}$ & $\begin{array}{c}0.94 \\
(2.79)\end{array}$ \\
\hline Year 1995 & $\begin{array}{l}15.33^{* * *} \\
(3.18)\end{array}$ & $\begin{array}{r}-4.36^{*} \\
(2.31)\end{array}$ & $\begin{array}{c}-2.52 \\
(2.93)\end{array}$ \\
\hline Year 1998 & $\begin{array}{l}6.91^{* *} \\
(2.79) \\
\end{array}$ & $\begin{array}{c}-4.61^{* *} \\
(2.00) \\
\end{array}$ & $\begin{array}{c}0.33 \\
(2.56) \\
\end{array}$ \\
\hline Number of Observations & 2,647 & 2,647 & 2,647 \\
\hline Pseudo R-Squared & 0.095 & 0.045 & 0.077 \\
\hline
\end{tabular}


Table 8: Determinants of the Relative Propensity to Contribute vs. Prepay This table summarizes the determinants of the relative preference for retirement contributions relative to mortgage prepayments for households from the 1995, 1998, and 2001 Surveys of Consumer Finances. The dependent variables are ratios of contributions to the sum of prepayments and contributions. The prepayments are defined as: (1) the difference between the actual payment on short mortgage and that on a 30-year mortgage, and (2) dollar amount of discretionary prepayments. The table summarizes the estimated coefficients of Tobit regressions, with robust standard errors in parentheses. The regressions also include unreported survey and mortgage origination year fixed effects. The significance levels are abbreviated with asterisks: ' $* * *$ ', '**', and '*' correspond to a $1 \%, 5 \%$, and $10 \%$ confidence levels, respectively.

\begin{tabular}{|c|c|c|c|c|}
\hline Variable & $\begin{array}{c}\text { Short } \\
\text { Mortgage }\end{array}$ & $\begin{array}{c}\text { Short } \\
\text { Mortgage }\end{array}$ & $\begin{array}{l}\text { Discretionary } \\
\text { Prepayments }\end{array}$ & $\begin{array}{l}\text { Discretionary } \\
\text { Prepayments }\end{array}$ \\
\hline MAP & $\begin{array}{l}1.04^{* * *} \\
(0.08)\end{array}$ & $\begin{array}{l}0.70^{* *} \\
(0.32)\end{array}$ & $\begin{array}{l}-0.26^{* *} \\
(0.12)\end{array}$ & $\begin{array}{c}-1.03^{* *} \\
(0.49)\end{array}$ \\
\hline $\mathrm{MAP}^{*}$ College & & $\begin{array}{l}0.75^{* * *} \\
(0.15)\end{array}$ & & $\begin{array}{c}0.22 \\
(0.24)\end{array}$ \\
\hline MAP*Prof. Advice & & $\begin{array}{l}0.62^{* * *} \\
(0.15)\end{array}$ & & $\begin{array}{c}-0.21 \\
(0.23)\end{array}$ \\
\hline MAP*Risk Aversion & & $\begin{array}{c}-0.12 \\
(0.09)\end{array}$ & & $\begin{array}{c}0.18 \\
(0.14)\end{array}$ \\
\hline MAP*Debt Averse & & $\begin{array}{r}0.27^{*} \\
(0.15)\end{array}$ & & $\begin{array}{c}0.32 \\
(0.23)\end{array}$ \\
\hline MAP*No TDA Penalty & & $\begin{array}{c}0.22 \\
(0.35)\end{array}$ & & $\begin{array}{r}0.002 \\
(0.52)\end{array}$ \\
\hline Liquidity Constrained & $\begin{array}{l}0.14^{* *} \\
(0.07)\end{array}$ & $\begin{array}{c}0.10 \\
(0.07)\end{array}$ & $\begin{array}{c}0.14 \\
(0.10)\end{array}$ & $\begin{array}{c}0.13 \\
(0.14)\end{array}$ \\
\hline Log of Net Worth & $\begin{array}{c}-0.08^{* * *} \\
(0.02)\end{array}$ & $\begin{array}{c}-0.08^{* * *} \\
(0.02)\end{array}$ & $\begin{array}{c}0.01 \\
(0.02)\end{array}$ & $\begin{array}{c}0.004 \\
(0.02)\end{array}$ \\
\hline Risk Aversion & $\begin{array}{c}-0.10^{* * *} \\
(0.03)\end{array}$ & $\begin{array}{c}-0.10^{* * *} \\
(0.03)\end{array}$ & $\begin{array}{c}-0.05 \\
(0.04)\end{array}$ & $\begin{array}{c}-0.05 \\
(0.04)\end{array}$ \\
\hline Debt Averse & $\begin{array}{l}-0.12^{* *} \\
(0.05)\end{array}$ & $\begin{array}{l}-0.13^{* *} \\
(0.05)\end{array}$ & $\begin{array}{c}-0.35^{* * *} \\
(0.08)\end{array}$ & $\begin{array}{c}-0.36^{* * *} \\
(0.08)\end{array}$ \\
\hline College Education & $\begin{array}{c}0.08 \\
(0.05)\end{array}$ & $\begin{array}{c}0.08 \\
(0.05)\end{array}$ & $\begin{array}{c}0.10 \\
(0.07)\end{array}$ & $\begin{array}{c}0.07 \\
(0.07)\end{array}$ \\
\hline Use Professional Advice & $\begin{array}{r}-0.001 \\
(0.04)\end{array}$ & $\begin{array}{c}-0.004 \\
(0.04)\end{array}$ & $\begin{array}{c}-0.07 \\
(0.06)\end{array}$ & $\begin{array}{c}-0.06 \\
(0.07)\end{array}$ \\
\hline Employer TDA match (ppt) & $\begin{array}{l}0.02^{* * *} \\
(0.004)\end{array}$ & $\begin{array}{l}0.02^{* * *} \\
(0.004)\end{array}$ & $\begin{array}{l}0.03^{* * *} \\
(0.007)\end{array}$ & $\begin{array}{c}0.03^{* * *} \\
(0.007)\end{array}$ \\
\hline Age (in years) & $\begin{array}{c}-0.03^{* * *} \\
(0.003)\end{array}$ & $\begin{array}{c}-0.03^{* * *} \\
(0.003)\end{array}$ & $\begin{array}{l}0.004 \\
(0.004)\end{array}$ & $\begin{array}{l}0.01 \\
(0.005)\end{array}$ \\
\hline Not Subject to TDA penalty & $\begin{array}{l}0.06 \\
(0.10)\end{array}$ & $\begin{array}{c}0.04 \\
(0.10)\end{array}$ & $\begin{array}{c}-0.31^{* *} \\
(0.15)\end{array}$ & $\begin{array}{c}-0.34^{* *} \\
(0.16)\end{array}$ \\
\hline Number of Children & $\begin{array}{l}-0.05^{* *} \\
(0.02)\end{array}$ & $\begin{array}{l}-0.05^{* *} \\
(0.02)\end{array}$ & $\begin{array}{c}0.02 \\
(0.03)\end{array}$ & $\begin{array}{c}0.02 \\
(0.03)\end{array}$ \\
\hline Married & $\begin{array}{c}-0.04 \\
(0.07)\end{array}$ & $\begin{array}{c}-0.05 \\
(0.07)\end{array}$ & $\begin{array}{c}0.03 \\
(0.10)\end{array}$ & $\begin{array}{c}0.03 \\
(0.10)\end{array}$ \\
\hline Mortgage Insurance & $\begin{array}{l}0.11^{* *} \\
(0.05)\end{array}$ & $\begin{array}{l}0.11^{* *} \\
(0.05)\end{array}$ & $\begin{array}{c}0.06 \\
(0.08)\end{array}$ & $\begin{array}{c}0.05 \\
(0.08)\end{array}$ \\
\hline High Homestead Exemption & $\begin{array}{c}0.04 \\
(0.06)\end{array}$ & $\begin{array}{c}0.05 \\
(0.06)\end{array}$ & $\begin{array}{c}0.01 \\
(0.08)\end{array}$ & $\begin{array}{c}0.01 \\
(0.08) \\
\end{array}$ \\
\hline Number of Observations & 2,078 & 2,078 & 1,924 & 1,924 \\
\hline Number of Non-limit Observations & 668 & 668 & 398 & 398 \\
\hline Pseudo R-Squared & 0.133 & 0.149 & 0.034 & 0.035 \\
\hline
\end{tabular}

